\title{
LOYAL DENOMINATORISM AND THE FOURTEENTH AMENDMENT: NORMATIVE DEFENSE AND IMPLICATIONS
}

\author{
CHRISTOPHER R. GREEN*
}

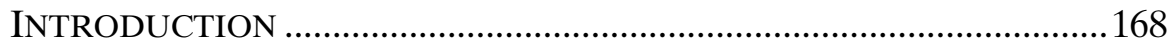

I. TACIT DOMAIN RESTRICTIONS IN PHILOSOPHY, HISTORY, AND

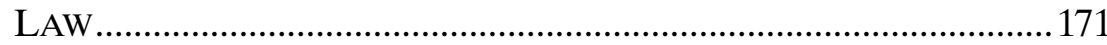

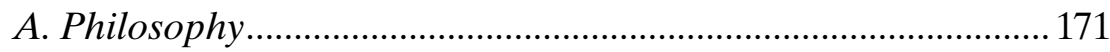

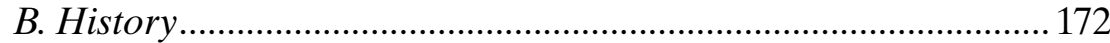

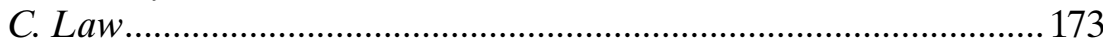

D. Tacit Domain Restrictions During the Civil War and

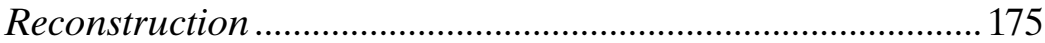

E. Is a Tacit Loyalty Requirement Too Vague? ................................ 176

II. "STATES” AS TACITLY LiMiTED TO “LOYAL STATES” .....................177

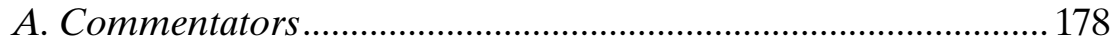

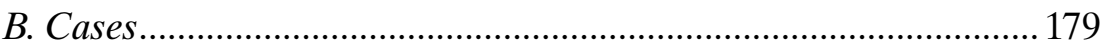

C. Was the Rebellion Confined to Individuals, Not States Themselves? ............................................................................ 183

III. END-OF-WAR LAW: VICTORS' POWER TO DELAY A CONDITION

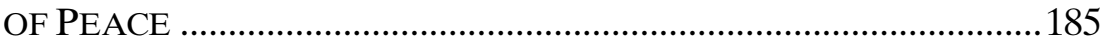

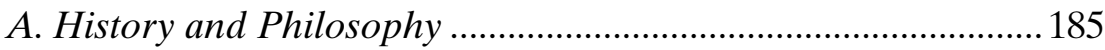

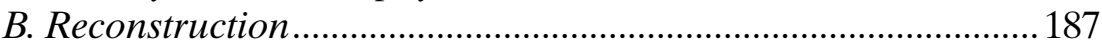

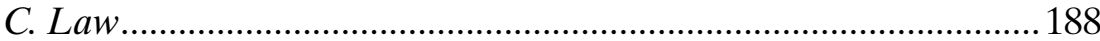

IV. THE SEPARATION OF WAR POWER ……........................................190

A. Congressional Power Over Wartime-Restriction Timing ..........190

B. Did Congress Pull the Trigger? ..................................................... 192

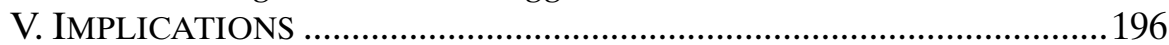

Copyright (C) 2017 Christopher R. Green.

*Associate Professor of Law and H.L.A. Hart Scholar in Law and Philosophy, University of Mississippi School of Law. Thanks to Bruce Ackerman, Larry Alexander, Akhil Amar, Will Baude, Tom Colby, Clark Gibbs, John Harrison, Gerard Magliocca, Jack Nowlin, Mike Ramsey, David Upham, and especially Mike Rappaport for discussion, and to the Lamar Order of the University of Mississippi for support. Please send comments to crgreen@olemiss.edu. 
A. Avoiding Ackerman, Amar, Colby, and Harrison's Lessons: Preserving Government by "Reflection and Choice".... 196

B. Jus post bellum, Southern Intransigence, and Lessons for

Democratic Theory..... 198

C. The Importance of Context in Interpretation. 204

D. Implications of Northern Authorship for the Fourteenth Amendment's Meaning. 205

CONCLUSION 208

\section{INTRODUCTION}

As the companion to this Article explains, ${ }^{1}$ controversy persists over exactly why the Fourteenth Amendment-the federal Constitution's most important provision-was legitimately adopted. Congress excluded representatives from the defeated South when it proposed the Amendment in 1866 (thereby allowing the two-thirds proposal votes in each house) and kept them out until Southern states ratified it in 1868 (thereby allowing a three-fourths ratification vote among states). Bruce Ackerman, Akhil Amar, John Harrison, and Thomas Colby offer four different theories to justify the Amendment. ${ }^{2}$ Ackerman finds such legitimacy in national politics and a new, nonArticle $\mathrm{V}$ ability to coerce state ratifications. ${ }^{3}$ Harrison finds a somewhat diluted form of legitimacy - "lawfulness" - in the formal lack of prohibition on such coercion, despite the fact that Article $\mathrm{V}^{4}$ was designed to prevent amendments without genuine three-fourths support among the states. ${ }^{5}$ Amar roots the amendment's legitimacy in

1. Christopher R. Green, The South Tried to Secede, and You'll Never Guess What Happened Next: Loyal Denominatorism and the Fourteenth Amendment, https://ssrn.com/abstract=2317471 [hereinafter STS].

2. Id. at 16-17, nn.23-26 and accompanying text.

3. 2 Bruce ACKerman, We the PEOPLE: TRANSFORMATIONS 233-49 (1998).

4. U.S. CONST. art. V ("The Congress, whenever two thirds of both Houses shall deem it necessary, shall propose Amendments to this Constitution ... which ... shall be valid to all Intents and Purposes, as Part of this Constitution, when ratified by the Legislatures of threefourths of the several States....").

5. John Harrison, The Lawfulness of the Reconstruction Amendments, 68 U. CHI. L. REV. 375, 457-58 (2001) (asserting that the purpose of Article V was to prevent constitutional change opposed by a sectional coalition in control of more than one-fourth of the states). Lawrence Tribe distinguished "lawfulness" from "legitimacy" in a tweet following John Lewis's attack on President Trump's legitimacy. Laurence Tribe (@tribelaw), TwITTER (Jan. 16, 2017, 3:40 AM), https://goo.gl/1F5QWi ("I revere John Lewis but think it might've helped for him to distinguish 'legitimate' from 'lawful[.]' A lawful POTUS can still be illegitimate.”). 
use of Article IV $^{6}$ to support a federal demand for black suffrage. Colby roots the Amendment's legitimacy in its morally-justified use (as Colby sees it) by later generations. ${ }^{8}$

Rather than nationalizing, democratizing, formalizing, or intergenerationalizing the constitutional author of the Fourteenth Amendment, this Article and its companion defend still a fifth tack: excluding rebel States from the Article V denominator. We the People who enacted the Fourteenth Amendment were We the Reliably Loyal People, exercising their jus post bellum rights prior to re-establishing legal peace. The Fourteenth Amendment became law on February 12, 1867, when 20 of the 26 states exercising federal political power had ratified it, rather than in July 1868, when 28 of the full 37 states in the Union had done so. The Thirteenth Amendment on this view also gets a bit older, becoming law in June rather than December 1865.

Loyal denominatorism reads "the several States" in Article V-and kindred phrases in Articles I, II, and IV - to have a tacit limit to reliably loyal States with whom the federal government is legally in a state of peace. This sort of tacit limit is not an exotic, idiosyncratic theory fitting only the fevered minds of the likes of Charles Sumner and Thaddeus Stevens. The companion Article shows that this theory was articulated, and in compelling detail, by many other Republicans during Reconstruction-and was assumed even by then-Senator Andrew Johnson in 1861 - continuing through 1868, when many Republicans said the Fourteenth Amendment was already law even before Southern ratifications. ${ }^{9}$ Many commentators, like Joel Prentiss Bishop, John Codman Hurd, and J.W. Burgess, adopted this view. ${ }^{10}$

Moreover, they were right. This Article shows how a loyal denominator follows from: (1) commonplace ancient, medieval, and

6. U.S. CONST. art. IV, $\S 4$ ("The United States shall guarantee to every State in this Union a Republican Form of Government ....").

7. Akhil Amar, Lindsey Ohlsson Worth, \& Joshua Alexander Geltzer, Reconstructing the Republic: The Great Transition of the 1860s, in TRANSITIONS 114 (Austin Sarat ed., 2012); see also Akhil Reed Amar, The Lawfulness of Section 5-And Thus of Section 5, 126 HARV. L. REV. F. 109, 112 (2013) ("At a certain point, states with abysmal track records could be deemed unrepublican within the meaning of Article IV ....").

8. Thomas Colby, Originalism and the Ratification of the Fourteenth Amendment, 107 Nw. U. L. REV. 1627, 1681 (2013) (preferring "our own evolving understanding of the lofty freedoms that are guaranteed by the abstract terms of the Fourteenth Amendment" to the "outdated, and even-at-the-time highly controversial, nineteenth-century notions of liberty and equality that were held by the prevailing Unionists").

9. STS, supra note 1 , at $23 \mathrm{n} .38$ and accompanying text.

10. Id. at $60 \mathrm{n} .222,61 \mathrm{n} .226$, and $61 \mathrm{n} .228$ and accompanying text. 
contemporary insights into tacit limits in language; (2) universallyrecognized canons on agreements' tacit limits during armed conflict; (3) similarly uncontroversial jus post bellum rules governing the timing of the re-establishment of peace in the eyes of the law; and (4) congressional power to delay such re-establishment under its declarewar power. None of these steps requires us to venture beyond wellestablished, secure territory. Indeed, denying a loyal denominator requires resisting a nearly universal consensus of informed observers on at least one of these four points.

Section I of this Article explains the linguistic background to how we might read "the several States" in Article V as, in context, tacitly meaning "the several [reliably loyal] States"; this rebuts Harrison's hyper-textualist and formalist arguments to the contrary and shows why he himself, in inferring a tacit relationship between Article VI and other constitutional powers, uses such linguistic moves. Section II considers the specific canon of interpretation under the law of armed conflict that friendship-presupposing agreements are tacitly suspended when war breaks out between their parties. Section III considers how long such wartime suspension lasts: as long as the victor deems it necessary to achieve sufficient security for its victory. Section IV considers where such peacetime-delaying power lies in the American scheme: clearly Congress, which has the power to declare that a state of war (still) exists, and which, in the context of Reconstruction, declared in July 1866 that all "political relations" were suspended until Congress acted, and in March 1867 declared that former Confederate states besides Tennessee were even then still "rebel States."

Section V explains four implications of this view of Fourteenth Amendment legitimacy. First, by narrowing the scope of the Article V actor, we eliminate coercion from the process of constitutional adoption and see its adoption as the product of "reflection and choice" by the loyal North. Second, moving up the date of the Fourteenth Amendment's adoption requires us to reclassify Reconstruction Act coercion of the South as part of the Amendment's enforcement, rather than its adoption. This move properly frames Southern intransigence in response to the Fourteenth and Fifteenth Amendments as a jus post bellum problem, shows the folly of the fiction that all states in the Union stand as equal sovereigns, and illuminates how the Constitution presents itself on a take-it-or-leave-it basis. Third, this Article's argument shows why context-sensitive tacit restrictions are important in assessing the Constitution's original meaning. Fourth, a Northern 
author affects the Fourteenth Amendment's meaning in cases like Brown v. Board of Education, ${ }^{11}$ McDonald v. Chicago, ${ }^{12}$ and for the history of substantive due process.

\section{TACIT DOMAIN RESTRICTIONS IN PHILOSOPHY, HISTORY, AND LAW}

John Harrison, one of the few contemporary thinkers to explicitly consider and reject a loyal Article $\mathrm{V}$ denominator, bases his argument on the text: "Article V, however, is pretty clear about this: three-fourths of the states. If South Carolina was still a state, it counted."13 At first glance, this argument may seem compelling, at least to a textualist (like $\mathrm{me}^{14}$ ). But the text only expresses meaning in a context, and that context supplies implicit domain limitations.

\section{A. Philosophy}

Tacit restrictions on quantifier domain are a well-worn part of modern linguistics and philosophy of language. As Larry Solum noted in one of his classic parodies, using current philosophy of language and linguistics to interpret an eighteenth-century text is akin to using modern chemistry to understand an eighteenth-century explosion. ${ }^{15}$ Modern philosophers and linguists regularly avert to "tacit quantifier domain restriction" to explain various bits of linguistic data. Daniel Korman uses a well-worn example:

If I were to open the fridge in search of beer and say 'there is no beer,' what you would probably understand me to be saying is that there is no beer in the fridge. In other words, you would take me to be tacitly restricting the domain of my quantifier to things in the fridge. ${ }^{16}$

11. 347 U.S. 483 (1954).

12. 561 U.S. $742(2010)$.

13. Harrison, supra note 5 , at 421 .

14. See, e.g., Christopher R. Green, "This Constitution”: Constitutional Indexicals as a Basis for Textualist Semi-Originalism, 84 NOTRE DAME L. REV. 1607 (2009).

15. Larry Solum, Rakove on the Historical Case for Original Ideas Originalism, LEGAL THEORY BLOG, (Apr. 1, 2016, 12:31 PM), http://lsolum.typepad.com/legaltheory/2016/04/rakoveon-the-historical-case-for-original-ideas-originalism.html ("Using Grice's theory of meaning to understand an eighteenth century text is no more sensible than using twentieth century chemistry to understand an eighteenth century explosion.").

16. DANIEL Z. KoRMAN, OBJECTS: NOTHING OUT OF THE ORDINARY 42 (2015). The beerin-the-fridge example goes back at least to DAVID K. LEWIS, ON THE PLURALITY OF WORLDS 136 (1986) ("[W]hen I say such things, I am restricting my quantifers, just as when I look in the fridge and say that there is no beer. I do not deny that there is beer outside the fridge, but I ignore it in my speech.”). 
Kai von Fintel notes that "all quantifiers have a hidden domain argument, whose value is contextually supplied." ${ }^{17}$ Tacit, contextuallysupplied restrictions on interpreting quantifiers in natural language is not-like, say, the analytic-synthetic distinction ${ }^{18}$-an issue on which philosophers disagree; contemporary philosophers and linguists take it as an uncontroversial datum to be explained.

\section{B. History}

While the most sophisticated tools available should be used to understand how language operates and had operated in the past, the same basic idea was well known as long ago as Aristotle. The Nicomachean Ethics defend equitable interpretation to correct the "error through speaking without qualification" (sometimes translated "oversimplicity") of the outward form of language ${ }^{19}$ while the Rhetoric likewise argues that because "no exact definition is possible, but legislation is necessary," and because of the "infinite number of cases," we must interpret legislators' work equitably. ${ }^{20}$ Aristotle's example was a penalty enhancement for striking a victim with an iron; an assailant who happened to wear an iron ring might fall under a hyper-literal reading of the enhancement, but the enhancement should be interpreted to apply only to those who strike others with an iron when

17. Kai von Fintel, Restrictions on Quantifier Domains 28 (May 1994) (unpublished Ph.D. dissertation, University of Massachusetts) (on file with the Duke Journal of Constitutional Law \& Public Policy); cf. Jason Stanley \& Timothy Williamson, Quantifiers and Context-Dependence, 55 ANALYSIS 291, 291 (1995) ("As is familiar, the truth of an utterance of a sentence containing a quantified expression must be evaluated with respect to a contextually determined domain."); Jason Stanley \& Zoltan Szabo, On Quantifier Domain Restriction, 15 Mind \& LANGUAGE 219, 219 (2000) ("The topic of this paper is the problem of quantifier domain restriction, which is a special case of the problem of context dependence."); LEWIS, supra note 16, at 164 ("[P]art of the ordinary meaning of any idiom of quantification consists in the susceptibility to restrictions; and that restrictions come and go with the pragmatic wind."); FRANCOIS RECANTI, LITERAL MEANING 87 (2004) (disagreeing with Stanley and Szabo's treatment of tacit quantifier domain restriction, but treating the phenomenon itself as utterly uncontroversial); id. at $104 \mathrm{n} .11$ (noting history of idea in modern linguistics).

18. See THE PhILPAPERS SurVEYs, https://goo.gl/LPaEUK (last visited Oct. 6, 2017) (finding, in a November 2009 survey, that $64.9 \%$ of philosophers say "yes" or "lean toward" saying "yes" to analytic-synthetic distinction, $27.1 \%$ "no" or "lean no").

19. Aristotle, Nicomachean Ethics 5.10.5 175 (F. H. Peters trans., 5th ed. 1893).

20. ARISTOTLE, RHETORIC 1.13.13-14 147 (Freese trans., 1947) ("[B]eing unable to define for all cases, [legislators] are obliged to make a universal statement, which is not applicable to all, but only to most, cases; and whenever it is difficult to give a definition owing to the infinite number of cases, as, for instance, the size and kind of an iron instrument used in wounding; for life would not be long enough to reckon all the possibilities. If then no exact definition is possible, one must have recourse to general terms."). 
the iron makes the assault more serious. ${ }^{21}$ This domain restriction is tacit.

English law's use of the same idea was discussed extensively by multiple authors. Discussing tacit insanity or infancy defenses and relying on Aristotle, Edmund Plowden noted in 1574 that "this correction of the general words is much used in the law of England." 22 Coke's Institutes noted in 1639 that equitable interpretation was required because "the Law-maker could not possibly set downe all cases in expresse termes." ${ }^{23}$ Isaac Watts noted in a 1724 textbook that quantifiers like "all, every, whatsoever" are, depending on the context, "used in a more extensive, or more limited sense." ${ }^{4}$ Emer de Vattel in 1758 noted that there are "exceptions so clear, that it is unnecessary to express them." ${ }^{25}$ Blackstone in 1768 noted that tacit equitable exceptions were required because "all cases cannot be foreseen; or, if foreseen, cannot be expressed." 26 Also following Aristotle, James Wilson noted in 1790 that equitable interpretation was required because it was "impossible to specify or to foresee every case." 27

\section{Law}

Moreover, recognizing tacit restrictions on the domains of constitutional and statutory language has always been commonplace at the Supreme Court. McCulloch v. Maryland's discussion of "necessary" notes the importance of context in explaining precisely what constitutional language expresses. Marshall explained:

21. See id. ("[I]f a man wearing a ring lifts up his hand to strike or actually strikes, according to the written law he is guilty of wrongdoing, but in reality he is not; and this is a case for equity.").

22. Eyston v. Studd, 75 Eng. Rep. 688, 696 (1574) (U.K.).

23. 2 EDWARD COKE, Institutes of the Lawes of England, in THE SELECTED WRITINGS AND SPEECHES OF SIR EDWARD COKE 573, 682 (Steve Sheppard ed., 2003) (1639).

24. IsAaC WATtS, LOGIC: OR, THE RIGHT USE OF REASON IN THE INQUIRY AFTER TRUTH 60 (1792) (1724). Watts discusses quantifiers as part of an extended explanation of the ways in which words can be "equivocal," a discussion similar to Madison's discussion of language in the Federalist Papers. See Alexander Hamilton et Al., The Federalist 183 (Carey \& McClellan eds. 2001) (No. 37, James Madison) ("All new laws, though penned with the greatest technical skill, and passed on the fullest and most mature deliberation, are considered as more or less obscure and equivocal, until their meaning be liquidated and ascertained by a series of particular discussions and adjudications."). The second item in Madison's papers is a series of notes on Watts's textbook, likely prepared at Princeton. See 1 THE PAPERS OF JAMES MADISON 32-42 (Hutchinson \& Rachal eds., 1962), https://founders.archives.gov/documents/Madison/0101-02-0003.

25. Emer de VAtTel, The Law of Nations 427 (Béla Kapossy \& Richard Whatmore eds., 2008) (1758) (citing Seneca the rhetorician).

26. 2 WiLliam BLACKSTONE, COMMENTARIES $* 430$.

27. 2 JAMES WILSON, Lectures on Law, in COLlECTED WORKS OF JAMES WILSON 924 (Kermit L. Hall \& Mark David Hall eds., Liberty Fund 2007) (1790) (part 2, chapter 3). 
Almost all compositions contain words, which, taken in their rigorous sense, would convey a meaning different from that which is obviously intended. It is essential to just construction, that many words which import something excessive, should be understood in a more mitigated sense-in that sense which common usage justifies. ... A thing may be necessary, very necessary, absolutely or indispensably necessary. To no mind would the same idea be conveyed by these several phrases. ${ }^{28}$

In 1919 and 1920, the Supreme Court endorsed tacit restriction to the Article $\mathrm{V}$ denominator - albeit at the proposal stage, rather than at ratification-in two cases concerning veto overrides ${ }^{29}$ and the Eighteenth Amendment. ${ }^{30}$ The Court held that only two thirds of those voting, not two thirds of the entire membership of the houses of Congress, was required to propose an amendment. This precise denominator was not set out in the text of Article V, but only implicit from context. Only those participating in the amendment-proposal process counted in setting the proposal denominator. An analogous principle would similarly limit the ratification denominator to those states participating in federal political power.

The commonplace nature of tacit limits to language was clear in 1994. Echoing Plowden's 1574 discussion of implicit mens rea requirements, the Court inferred a knowledge requirement for the criminalization of machine-gun possession, despite "[s]ilence" in the statute. ${ }^{31}$ The concurrence and dissent quarreled only with whether an implicit exception was warranted in the case, not with the general principle of tacit contextual limits. ${ }^{32}$

A tacit loyalty requirement for Article I, Article II, or Article V power can be seen as a tacit "good mind" restriction analogous to the "bad mind" inferences of the criminal law. Insane people are not subject to the facially-exceptionless words of the criminal law, and rebellious States likewise cannot partake of facially-exceptionless federal political power in the Constitution.

28. McCulloch v. Maryland, 17 U.S. 316, 414 (1819).

29. Mo. Pac. Railway v. Kansas, 248 U.S. 276, 281-84 (1919) (discussing history of limited Article V proposal denominator beginning from the Bill of Rights).

30. Prohibition Cases, 253 U.S. 350, 386 (1920) (briefly following Missouri Pacific).

31. Staples v. United States, 511 U.S. 600, 619 (1994); $c f$. Morissette v. United States, 342 U.S. 246, 252 (1952) (inferring mens rea "even if their enactments were silent on the subject").

32. See Staples, 511 U.S. at 621 (Ginsburg, J., concurring) (noting that government conceded existence of implicit mens rea requirement, quarreling only with its precise content); $i d$. at 626 (Stevens, J., dissenting) ("[T]he lack of an express knowledge requirement... is not dispositive...."). 


\section{Tacit Domain Restrictions During the Civil War and Reconstruction}

While Harrison finds clarity in the simple, unqualified word "states" in Article V, everyone during Reconstruction acknowledged the existence of some tacit conditions on states' powers under the Constitution. The most radical theory denied even President Johnson's ability to impose additional conditions, but taking the Article VI oath was seen as a bare minimum..$^{33}$ Indeed, Harrison himself interprets Article VI as tacitly limiting Article I powers:

Article VI indicates that a state government, in order to qualify as such, must through its law recognize the supremacy of federal law. [Harrison here simply footnotes Article VI itself.] Its officers must in general be bound by the Article VI oath. Hence whatever else they were, the organizations that sent senators to Richmond were not governments of United States. Article VI imposes a necessary condition for loyalty: a state government must represent itself as such in its law. ${ }^{34}$

This is not actually what Article VI says - not explicitly. The Article VI oath nowhere establishes itself explicitly as a condition precedent to Article I powers; officials are simply required to take the oath, and are not subject to any particular penalty if they do not. ${ }^{35}$ Harrison resists adding any further conditions like loyalty to the exercise of Article I powers beyond the Article VI oath, because "the Constitution does not indicate this explicitly." 36 But neither does it indicate a condition-precedent relationship between Article VI and Article I explicitly. The Office of Legal Counsel noted properly in 1985-an opinion to which President Obama's advisors apparently looked when considering whether to re-do his oath following its garbling at his first inauguration ${ }^{37}$ - that "the taking of the oath is not, strictly speaking, a prerequisite to assumption of the powers and duties of the

33. See William A. DunNing, EsSAYs On The Civil WaR AND ReCONSTRUCtion AND RELATED TOPICS 102 (1897) ("[I]t became the duty of the officers to take the oath required by the constitution, of the legislature to provide for the dispatch of congressmen to Washington, and of the people of the state to submit to the authority of the courts and officials of the national government. These steps having being taken, the Union would stand under the constitution as before the war.").

34. Harrison, supra note 5, at 431.

35. See U.S. CONST. art. VI, cl. 3 ("The Senators and Representatives before mentioned, and the Members of the several State Legislatures, and all executive and judicial Officers, both of the United States and of the several States, shall be bound by Oath or Affirmation, to support this Constitution ....").

36. Harrison, supra note 5, at 432.

37. See JefFrey Toobin, The OAth 4, 1-15 (2012). 
Presidency." ${ }^{38}$ Resolving when statutory or constitutional provisions tacitly establish conditions precedent to other provisions is sometimes quite difficult. ${ }^{39}$ It is a mistake to pretend that these relationships between provisions are actually explicit simply because the first provision is set out in the text.

Similarly, even if Southern governments were not republican in form under Article IV ${ }^{40}$ jumping to those governments' lack of Article I powers would also require tacit conditions in Article I. The question is not whether there are tacit conditions at all, but what those tacit conditions are.

\section{E. Is a Tacit Loyalty Requirement Too Vague?}

Harrison is right that "the concept of loyalty [is] both vague and difficult to implement." ${ }^{41}$ But sometimes the Constitution is vague and difficult to implement. On this issue too, Aristotle had it right:

We must be content if we can attain to so much precision in our statement as the subject before us admits of .... [W]e must be content if we can indicate the truth roughly and in outline .... [I]t is the mark of an educated man to require, in each kind of inquiry, just so much exactness as the subject admits of: it is equally absurd to accept probable reasoning from a mathematician, and to demand scientific proof from an orator. ${ }^{42}$

Macaulay's answer to the doctrine of absolute non-resistance to the king, which he analogizes to self-defense, eloquently strikes a similar theme:

A good action is not distinguished from a bad action by marks so plain as those which distinguish a hexagon from a square. There is a

38. Operation of the Twenty-Fifth Amendment Respecting Presidential Succession, 9 Op. O.L.C. 65,67 (1985).

39. See, e.g., State Farm Fire \& Casualty Co. v. United States ex rel. Rigsby, 137 S. Ct. 436, 442 (2016) (explaining that while the seal requirement for False Claim Act relators is mandatory, its breach does not necessarily mean that the case must be dismissed; "[a]lthough the duty is mandatory, the sanction for breach is not loss of all later powers to act") (quoting United States v. Montalvo-Murillo, 495 U.S. 711, 718 (1990)); In re Hooker, 87 So. 3d 401, 403 (Miss. 2012) (breach of publication requirement does not invalidate subsequent pardon, even though that requirement is mandatory).

40. See, e.g., Amar, The Lawfulness of Section 5-And Thus of Section 5, supra note 7, at 112 ("At a certain point, states with abysmal track records could be deemed unrepublican within the meaning of Article IV ....").

41. Harrison, supra note 5, at 432; see also id. at 421 (explaining that a loyal denominator would "introduc[e] another layer of uncertainty into Article V, which performs its function better the clearer it is").

42. ARISTOTLE, supra note 19, at 3-4 (section 1.3) (emphasis added). 
frontier where virtue and vice fade into each other.... All our jurists hold that a certain quantity of risk to life or limb justifies a man in shooting or stabbing an assailant: but they have long given up in despair the attempt to describe, in precise words, that quantity of risk ... . A man beset by assassins is not bound to let himself be tortured and butchered without using his weapons, because nobody has ever been able precisely to define the amount of danger which justifies homicide. Nor is a society bound to endure passively all that tyranny can inflict, because nobody has ever been able precisely to define the amount of misgovernment which justifies rebellion. ${ }^{43}$

Harrison's demand for precision in Article $\mathrm{V}$ at the cost of abandoning the power of constitutional amendment during the war contrasts sharply with his toleration of some vagueness in other Fourteenth Amendment contexts. He correctly reads the Privileges or Immunities Clause as a general ban on second-class citizenship, ${ }^{44}$ a concept whose boundaries will undoubtedly be fuzzy. ${ }^{45}$ Harrison noted famously in defense of that fuzziness, "I do not suggest that there are easy answers to the questions thus formulated, but they have the virtue of being the Constitution's questions rather than our own." 46 This is exactly right; if, in context, some of the Constitution's provisions have vague tacit limits on their domains, our desire for a precise Constitution will be unsatisfied.

\section{II. "STATES" AS TACITLY LiMITED TO "LOYAL STATES"}

Harrison's concern about the vagueness of a tacit limit on constitutional powers is, however, a real one: equitable interpretation can seem to open the door to freewheeling textual revision and a simple refusal to obey controlling authority. Even while they argued that tacit domain restrictions were inevitable, Vattel in 1758 noted the need to be

43. 2 ThOMAs Babington MaCAUlay, History of ENGLAND From the ACCESSION OF JAMES II 305 (chapter 9) (Harper \& Brothers ed., 1850) (hyphenation and emphasis added).

44. John Harrison, Reconstructing the Privileges or Immunities Clause, 101 YALE L.J. 1385, 1388-89 (1992) ("[A]n amendment that forbade the states from abridging privileges or immunities would ban caste legislation with respect to citizens' rights ....”).

45. Christopher R. GReen, EQual Citizenship, Civil Rights, AND the

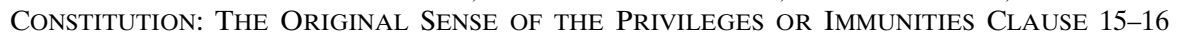
(2015) [hereinafter EQUAL CITIZENSHIP] (giving similar equal-citizenship-focused reading, and noting Republican acknowledgment during Reconstruction of the Clause's imprecise boundaries).

46. Harrison, supra note 44, at 1389; cf. McDonald v. Chicago, 561 U.S. 742, 855 (2010) (Thomas, J., dissenting) ("To be sure, interpreting the Privileges or Immunities Clause may produce hard questions. But they will have the advantage of being questions the Constitution asks us to answer."). 
"very cautious and moderate" in inferring tacit exceptions, ${ }^{47}$ while Wilson in 1790 urged the "greatest circumspection." 48

One way to be cautious and circumspect is to carefully examine how interpretive domain-restriction conventions have been used in the past. Made-up interpretive tacit domain restrictions give others reason to be skeptical. Loyal denominatorism, however, need not resort to ad hocery. It can rely on a tacit restriction well-recognized long before the Constitution was adopted: the suspension of friendship-presupposing relationships while their constituents are at war with each other. This rule undergirds the consensus the Court noted in 1869 in Texas v. White: "All admit that, during this condition of civil war, the rights of the State as a member, and of her people as citizens of the Union, were suspended." 49

\section{A. Commentators}

A long line of thinkers about the law of armed conflict have held that friendly commerce among the subjects of warring powers is implicitly suspended during war. Grotius explained in 1625, "War denounced against a Sovereign, is presumed at the same Time to be denounced, not only against all his Subjects, but also others who shall join him, and who ought to be considered, in Regard to him, only as an Accessory." ${ }^{50}$ Jean-Jacques Burlamaqui explained in 1747 why treaties of commerce were tacitly restricted during war: "As soon as war has been declared against a sovereign, it is presumed to be declared at the same time not only against all his subjects, who, in conjunction with him, form one moral person. ${ }{ }^{5}$

Vattel framed this rule as a "tacit supposition of the continuance of peace" in 1758 :

The conventions, the treaties made with a nation, are broken or annulled by a war arising between the contracting parties, either because those compacts are grounded on a tacit supposition of the continuance of peace, or because each of the parties, being

47. VATTEL, supra note 25 , at 430 .

48. WILSON, supra note 27 , at 924 .

49. Texas v. White, 74 U.S. 700, 727 (1869)

50. 3 Hugo Grotius, The Rights of WAR AND Peace 1265 (Richard Tuck ed., 2005) (1625) (bk. 3, ch. 3, § 9); cf. id. at 1281 (bk. 3., ch. 4, § 8) ("[W]hen War is proclaimed against a Nation, it is at the same Time proclaimed against all of that Nation ....").

51. 2 JEAN-JACQUES BURLAMAQUI, THE PRINCIPLES OF NATURAL AND POLITIC LAW 485 (Petter Korkman ed., Thomas Nugent trans., 2006) (1748) (bk. 2, pt. 4, ch. 4, § 20). 
authorised to deprive his enemy of what belongs to him, takes from him those rights which he had conferred on him by treaty. ${ }^{52}$

Vattel's basic rule is that agreements intended to govern hostile relationships would still be in effect during a war-the Geneva Conventions governing jus in bello would be obvious modern examples-but that amity-presupposing agreements like treaties of commerce would not. This rule has been followed with remarkable unanimity by later interpreters. Chancellor James Kent held in 1832 that "obligations of treaties are dissipated by hostility" except for "stipulations which contemplate a state of future war, and make provision for such an exigency." 53 Henry Wheaton, citing Vattel and Kent, noted in 1836, "Treaties, properly so called, or foedera, are those of friendship and alliance, commerce and navigation ... which even if perpetual in terms, expire of course ... [i]n case of war between the contracting parties; unless such stipulations as are made expressly with a view to a rupture ...."54

\section{B. Cases}

A long line of cases and arbitrations has applied this distinction between hostility-presupposing and amity-presupposing agreements. This includes a surprisingly large number related to the suspension of the 1794 Jay Treaty during the War of $1812 .{ }^{55}$ In 1814, the Supreme Court through Justice Johnson noted that war cut off any "[i]ntercourse inconsistent with actual hostility," such as ordinary commerce. ${ }^{56}$ The Court explained, "In the state of war, nation is known to nation only by their armed exterior; each threatening the other with conquest or annihilation. The individuals who compose the belligerent states, exist, as to each other, in a state of utter occlusion. If they meet, it is only in combat." ${ }^{57}$ Following Grotius, Burlamaqui, and Vattel, Chancellor Kent decided in 1819, "[T] he idea that any commercial intercourse or pacific

52. VATTEL, supra note 25 , at $576(3.10, \S 175)$. Vattel then made an exception for "those treaties by which certain things are stipulated in case of a rupture," reasoning that "by treaties of this nature, we mean to provide for what shall be observed in case of a rupture," and so "we renounce the right of cancelling them by a declaration of war." Id. at 576-77.

53. 1 JAMES KENT, COMMENTARIES ON AMERICAN LAW 165 (1826).

54. HENRY WHEATON, ELEMENTS OF INTERNATIONAL LAW 191 (section 3.2.8) (1836); see also id. at 369 (section 4.4.3) ("[D]ebts previously contracted between the respective subjects, though the remedy for their recovery is suspended during the war, are revived on the restoration of peace.").

55. Most of these provisions concerned the relationship between the United States and Canada, especially Atlantic fishing rights. See, e.g., infra note 61 and accompanying text.

56. The Rapid, 12 U.S. (8 Cranch) 155, 163 (1814).

57. Id. at 160-61. 
dealing could lawfully subsist between them [American citizens and British subjects], without the clear and express sanction of the government, is utterly inconsistent with the new class of duties growing out of a state of war." 58 This rule applied "even though no express prohibition of trade should be issued." ${ }^{59}$ In 1823, the Supreme Court held that "treaties stipulating for permanent rights, and general arrangements, and professing to aim at perpetuity" were not completely abrogated by war, but "only suspended while it lasts." ${ }^{100}$ The abrogation-versus-suspension issue, still involving the War of 1812, was at stake in the 1910 fisheries dispute between the U.S. and Britain. ${ }^{61}$

In 1920, applying the same friendship-presupposing-versus-warcompatible distinction set out by Vattel, Kent, and Wheaton, future Justice Cardozo waxed lyrical on the difficulty of determining whether a particular treaty presupposed friendship between warring nations:

The effect of war upon the existing treaties of belligerents is one of the unsettled problems of the law .... International law to-day does not preserve treaties or annul them regardless of the effects produced. It deals with such problems pragmatically, preserving or annulling as the necessities of war exact. It establishes standards, but it does not fetter itself with rules .... This does not mean, of course, that there are not some classes of treaties about which there is general agreement. Treaties of alliance fall. Treaties of boundary or cession, "dispositive" or "transitory" conventions, survive .... So, of course, do treaties which regulate the conduct of hostilities .... Intention in such circumstances is clear. These instances do not represent distinct and final principles. They are illustrations of the same principle. They are applications of a standard. When I ask what that principle or standard is, and endeavor to extract it from the long chapters in the books, I get this, and nothing more, that provisions compatible with a state of hostilities, unless expressly terminated, will be enforced, and those incompatible rejected. ${ }^{62}$

Cardozo agreed with the Institute of International Law: "Treaties of alliance, those which establish a protectorate or a sphere of influence,

58. Griswold v. Waddington, 16 Johns. 438, 447 (N.Y. 1819).

59. Id. at 460.

60. Soc'y for the Propagation of the Gospel v. New Haven, 21 U.S. (8 Wheat.) 464, 494-95 (1823).

61. See Arnold Pronto, The Effect of War on Law-What Happens to Their Treaties when States Go to War?, 2 CAMB. J. INT'L \& COMP. L. 227, 228 (2013) ("Contemporary international law recognises [sic] an intermediate position, whereby treaties between parties to an armed conflict might be automatically suspended for the duration of the conflict, only to be revived afterwards .....").

62. Techt v. Hughes, 229 N.Y. 222, 240-41 (1920). 
and generally treaties of a political nature, are, it is said, dissolved." $" 63$ The "political" language goes back at least to Carlos Calvo's 1863 French treatise: "[A]ll are agreed in admitting the rupture of conventional ties concluded expressly with a view to a state of peace, of those whose special object is to promote relations of harmony between nation and nation, such as treaties of amity, of alliance, and other acts of the same nature having a political character." ${ }^{64}$ Cecil Hurst noted in 1922, "In general . . . treaties between the belligerents concluded with a political object are abrogated by war." 65

In 1929, the Supreme Court used similar "political character" language to describe which agreements would be inconsistent with war:

The law of the subject is still in the making, and, in attempting to formulate principles at all approaching generality, courts must proceed with a good deal of caution. But there seems to be fairly common agreement that at least the following treaty obligations remain in force: stipulations in respect of what shall be done in a state of war; treaties of cession, boundary, and the like; provisions giving the right to citizens or subjects of one of the high contracting powers to continue to hold and transmit land in the territory of the other; and, generally, provisions which represent completed acts. $O n$ the other hand, treaties of amity, of alliance, and the like, having a political character, the object of which is to promote relations of harmony between nation and nation, are generally regarded as belonging to the class of treaty stipulations that are absolutely annulled by war. ${ }^{6}$

Later cases $^{67}$ and the ALI's 1987 Restatement of the Foreign Relations Law of the United States ${ }^{68}$ follow Techt and Karnuth as the latest word on the wartime treaty-suspension rule.

States' powers under the Constitution presuppose friendship and amity between states and the Union. Whatever difficulties exist in classifying wartime-suspended versus wartime-operational agreements,

63. Id. at 242 .

64. J.B. Moore, The Effect of War on Public Debts and on Treaties - The Case of the Spanish Indemnity, 1 COLUM. L. REV. 209, 220 (1901) (translating and quoting "the great work of Calvo," Droit Int., 4th ed., IV, 65, sec. I, noting that this rule was "universally accepted").

65. Cecil J. Hurst et al., The Effect of War on Treaties, 2 BRIT. Y.B. INT'L. L. 37, 42 (1922).

66. Karnuth v. United States, 279 U.S. 231, 236-37 (1929) (citation omitted and emphasis added).

67. See e.g., Clark v. Allen, 331 U.S. 503, 508 (1947) ("There may of course be such an incompatibility between a particular treaty provision and the maintenance of a state of war as to make clear that it should not be enforced.").

68. Restatement of THE LAW, THiRd, Foreign Relations LAW OF THE UNited STATES § 336, reporters' note 4 (AM. LAW INST. 1987) (noting Techt, Karnuth, and Clark). 
States' political powers in the federal government in Articles I, II, and $\mathrm{V}$ are an easy case: they are inconsistent with a state of war, and hence are suspended.

In 1969, Article 73 of the Vienna Convention on the Law of Treaties shelved the question of wartime treaty suspension..$^{69}$ In 2011, however, the International Law Commission submitted draft articles to the United Nations General Assembly on the issue. The proposal follows cases like Karnuth and Techt in holding that war is incompatible with "political" agreements. ${ }^{70}$ Proposed Article 7 refers to an appendix listing several sorts of agreements which may "continue in operation, in whole or in part, during armed conflict." " Among these are agreements establishing international organizations, ${ }^{72}$ which are close analogues to the Constitution's establishment of the federal government. Such organizations can continue to operate during armed conflict, but "the continued participation of its members in the activities of the international organization" may, in some cases, be suspended. ${ }^{73}$ While it does not squarely resolve the issue posed during the Civil War, these comments on the power to participate in international organizations come the closest to framing the issue at stake during the Civil War. The framing suggests that current international law commentators recognize that the rationale of the rule regarding the watime suspension of friendship-presupposing agreements would apply to the participation of states in the federal government.

There is no principled distinction that prevents the tacitsupposition-of-peace principle from applying to states' powers under the Constitution. Tacit quantifier domain restriction is a general phenomenon of language, and is not limited to agreements like treaties between full nation states. If a peacetime-presupposition interpretive convention applies to private contracts, treaties, statutes, and regulations, it naturally applies to constitutions too. This does not mean that the Constitution has no force during a war. Vattel and those following him were perfectly aware that many treaty provisions do contemplate war without presupposing continued amity and friendship

69. Vienna Convention on the Law of Treaties art. 73, Jan. 27, 1980, 1155 U.N.T.S. 331, 8 I.L.M. 679 (1969) (refusing to "prejudge" issue).

70. Report from the United Nations, Draft Articles on the Effects of Armed Conflicts on Treaties, with Commentaries 7-8 nn.395-96 (2011), goo.gl/FkpUON.

71. Id. at 21.

72. Id.

73. Id. at 37 (noting the draft would not "prejudice" the issue). 
between the contracting parties. The Constitution likewise contemplates war in distributing war powers among Congress,${ }^{74}$ the President, ${ }^{75}$ and the States, ${ }^{76}$ limiting habeas suspension to "Cases of Rebellion or Invasion," 77 and distinguishing between the rules for "time of peace" and "time of war." 78 But it does not contemplate war by states against the federal government. Ex Parte Milligan, for instance, rightly struck down the use of military commissions to try cases in locations where courts are operating:

The Constitution of the United States is a law for rulers and people, equally in war and in peace, and covers with the shield of its protection all classes of men, at all times and under all circumstances. No doctrine involving more pernicious consequences was ever invented by the wit of man than that any of its provisions can be suspended during any of the great exigencies of government. ${ }^{79}$

The suspension of states' powers while they engage in illegal war is not based on a general suspension of the Constitution during war; it is limited only to relationships between the parties at war with each other. Lambdin Milligan could not himself be presumed to be at war with the federal government prior to adjudication; his constitutional rights were not suspended. But states that had formally passed resolutions of secession were at war with the Union; as the Court noted just three years later, their constitutional rights and powers were suspended.

\section{Was the Rebellion Confined to Individuals, Not States Themselves?}

Perhaps, though, the states were not actually in rebellion. When Mississippi said that its ties with the Union were dissolved, if secession was illegal, those ties were not actually dissolved. However, Mississippi did engage in war against the Union, and that is enough for suspension of its constitutional rights.

Harrison has suggested in conversation that Articles I and V are different because Article I powers require the existence of a lawful apparatus of officials to operate, but Article $\mathrm{V}$ naysaying powers do not. A group of legislators, or perhaps even a state legislature itself, can become disloyal by passing an ordinance of secession, and so rendering

\footnotetext{
74. U.S. CONST. art. I, § 8, cl. 11-16.

75. U.S. CONST. art. II, § 2, cl. 1 .

76. U.S. CONST. art. I, $\S 10$, cl. 3.

77. U.S. CONST. art. I, § 9, cl. 4.

78. U.S. CONST. amend. III.

79. 71 U.S. (2 Wall.) 2, 120-21 (1866).
} 
a state unable to exercise Article I or positive Article V powers. But, Harrison argues, a state itself cannot be disloyal, because if secession is illegal, there is no such thing as a disloyal, rebel state. Thus, the story would go, Southern states still possessed both Article I and Article V rights, but were simply unable to exercise Article I and Article V "yes" powers, for lack of lawfully-appointed legislatures. The Article V "no" power, however, requires no officials.

This disanalogy is uncompelling; it is no more incongruous to label states "rebel states," and yet still states in the Union, subject to the federal government's authority, than to label individual Americans "rebels," and yet still Americans subject to the federal government's authority. States act through their duly-authorized agents; qui facit per alium, facit per se (he who acts through another acts himself). It is no more impossible for a state to rebel than for a corporation to commit a crime. ${ }^{80}$ "If . . the invisible, intangible essence or air which we term a corporation can level mountains, fill up valleys, lay down iron tracks, and run railroad cars on them, it can intend to do it, and can act therein as well viciously as virtuously."

The idea that states themselves, by their nature, cannot rebel or be guilty of disloyalty is wrong for the same reason as the idea - "the old and exploded doctrine," the Supreme Court called it in $1909^{82}$ - that corporations can never commit crimes. The chief reason to adopt those conclusions uses the ipso facto ultra vires fallacy, a close cousin of the "no true Scotsman" fallacy: if an apparent state actor rebels, he must not really be acting on behalf of the state, but must be, in virtue of his rebellion, merely on a frolic of his own. ${ }^{83}$ No true agent of the state would rebel; no true corporate employee would commit a crime.

80. See N.Y. Cent. \& Hudson. R. R. Co. v. United States, 212 U.S. 481, 492-93 (1909) (recognizing that corporations could commit crimes despite the common law doctrine claiming that they could not). See Christopher R. Green, Theseus, Incorporated: Philosophy of Mind, Material Constitution, and the Ontology of the Criminal Law, for my philosophical defense, available at $\mathrm{http}: / / \mathrm{ssrn} . \mathrm{com} / \mathrm{abstract}=1949507$. See Christopher R. Green, Punishing Corporations: The Food-Chain Schizophrenia in Punitive Damages and Criminal Law, 87 NEB. L. REV. 197 (2008) for a survey of the unanimity among the states, both in criminal law and punitive damages, that corporations may properly be punished.

81. N.Y. Cent. \& Hudson, 212 U.S. at 493 (quoting 1 JoEL Prentiss Bishop, NeW COMMENTARIES ON THE CRIMINAL LAW UPON A NEW SYSTEM OF LEGAL EXPOSITION 255-56 (§ 417) (8th ed. 1892)).

82. Id. at 496.

83. See, e.g., Orr v. Bank of United States, 1 Ohio 36, 41 (1822) ("Trespass does not lie against a corporation, viz: by the name of corporation, but against the persons who did it, by their proper name .... As outlawry does not lie against an aggregate corporation, therefore trespass does not lie against them ....") (citation omitted). 
Definitions of "state" or "corporate action" that simply exclude certain state or corporate actions a priori as impossible are not likely to be useful legally.

It is true that the Supreme Court in the Prize Cases held that Congress "cannot declare war against a state" and that the President may not "initiate or declare a war ... against a ... State." ${ }^{84}$ But this is not because the states may not initiate war with the Union, for in the next breath the Court calls the Confederate states "states in rebellion." ${ }^{85}$ The states obviously rebelled through their secession conventions. The Court noted the consensus six years later: "All admit that, during this condition of civil war, the rights of the State as a member, and of her people as citizens of the Union, were suspended." 86 The Prize Cases Court did not establish any sort of principle that secession stained only individuals and not states; secession affected the rights of both.

\section{END-OF-WAR LAW: VICTORS' POWER TO DELAY A CONDITION OF PEACE}

If language has tacit restrictions on its coverage, and if one of those tacit restrictions is that friendship-presupposing agreements between are suspended "during wartime," who decides how long that lasts? The answer is, under well-established, uncontroversial armed-conflict law, as long as the victor deems it necessary to be secure in its victory. Standard jus post bellum and jus victoriae rules of armed-conflict law give victors a broad right to impose conditions before restoring the legal status quo ante.

\section{A. History and Philosophy}

In 1532, Francisco de Vitoria first described the right of those fighting in a just war to go beyond the specific object of the war to establish peace:

[A] prince may .... in a just war and do whatever is necessary in order to obtain peace and security from the enemy; for example, destroy an enemy's fortress and even build one on enemy soil, if this be necessary in order to avert a dangerous attack of the enemy. This is proved by the fact that, as said above, the end and aim of war is

84. Prize Cases, 67 U.S. (2 Black.) 635, 668 (1863).

85. Id. at 671 .

86. Texas v. White, 74 U.S. (7 Wall.) 700, 727 (1869); see also infra notes 132, 133 and accompanying text. 
peace and security. Therefore a belligerent may do everything requisite to obtain peace and security. ${ }^{87}$

Vitoria also approved using war to avenge wrong, a much more controversial point. But it was uncontroversial that those fighting a just war may properly demand security and freedom from risk regarding the object of the war, beyond bare attainment of the object itself. ${ }^{88}$

In 1625, Hugo Grotius also noted the victor's right to "security": "[A]s far as his own Security will permit it, it is honourable (to a Conqueror) to shew Clemency and Liberality." ${ }^{89}$ This fits with his general comment that in self-defense, "[I may] invade and seize upon what belongs to another" and "detain it till my Security be sufficiently provided for." 90 Samuel Pufendorf repeated the same idea in 1673: "Humanity commands me, as far as the Fury of War will permit, that I do my Enemy no more Harm, than the Defence or Vindication of my Right requires, with Care to my Security for the Time to come." ${ }^{91}$ Jean Barbeyrac explained in a 1724 note on Grotius,

[T] he Victor, who has possessed himself of an Enemy's Country, may command in it, whilst he holds it, and not resign it, till he has good Security, that he shall either obtain, or possess without Hazard, what is necessary for the Satisfaction and Amends he has a Right to exact by the Methods of Force. ${ }^{92}$

In 1758, Vattel gave the general understanding at the time of the immediate background to the Constitution:

When a sovereign has been compelled to take up arms for just and important reasons, he may carry on the operations of war till he has attained its lawful end, which is, to procure justice and safety .... [I]f we have to do with a perfidious enemy, it would be imprudent to trust either his words or his oaths. In such case, justice allows and prudence requires that we should avail ourselves of a successful war, and follow up our advantages, till we have humbled a dangerous and

87. FRANCISCO DE VITORIA, ON THE LAW OF WAR $\S 18$ (1532), reprinted in VITORIA: PoliticAl Writings 305 (Anthony Padgen \& Jeremy Lawrance eds., 1991) (emphasis added).

88. See infra notes 89 to 100 and accompanying text.

89. 3 GROTIUS, supra note 50, at 1586 ( $\$ 3.20 .50 .1$ ) (emphasis added).

90. Id., at 1186 ( $\$ 3.1 .2 .2)$ (emphasis added). Grotius here cites his earlier comment that one fighting a just war may take even neutrals' property as long as "he takes nothing but what is necessary for his Security." 2 GROTIUS, supra note 50, at 437 (\$ 2.2.10).

91. SAMUEl PUfENDORF, THE WHOLE DUTY OF MAN 240 (chapter 16) (Knud Haakonssen ed., 2003) (1673) (emphasis added).

92. 3 GROTIUS, supra note 50, at 1374 n.1 (\$ 3.8.1.1) (note added in French edition by Jean Barbeyrac; see 1 id. at $\mathrm{x})$. 
excessive power, or compelled the enemy to give us sufficient security .... ${ }^{93}$

Kant's comments on the jus post bellum in his 1796 Science of Right ("Right after War," he termed it ${ }^{94}$ ) are also instructive. He sets much stricter limits on transitioning from a state of war to one of peace than does Vitoria: neither punishment nor restitution of the cost of war is allowed. ${ }^{95}$ However, like earlier writers, Kant thinks those who win a just war are entitled to security against an unjust aggressor: "The conqueror lays down the conditions under which he will agree with the conquered power to form the conclusion of Peace."96 Kant denies that a victor has "the right to partition and appropriate the country, so as to make a state as it were disappear from the earth." ${ }^{97}$ He does, however, note that in giving security to the victor, the people may be required to "adopt such a new constitution as by its nature would be unfavourable to the inclination for war." 98 This is exactly what the North imposed on the South in 1867. Victory in a just war entitles the winner to get rid of risks and inclinations, not merely to repel an unjust act of aggression. ${ }^{99}$

\section{B. Reconstruction}

An armed-conflict winner's need for at least some measures of security were generally acknowledged during Reconstruction. There was great dispute about how large these measures should be, but it was

93. VATTEL, supra note 25 , at $654(4.1, \S 6)$.

94. IMMANUEL KANT, THE PHILOSOPHY OF LAW: AN EXPOSITION OF THE FUNDAMENTAL PRINCIPLES OF JURISPRUDENCE AS THE SCIENCE OF RIGHT (§ 58) 137 (William Hastie trans.,1887) (1796).

95. Id. at 137-38 ("Neither the conquered State nor its Subjects, lose their political liberty by conquest of the country, so as that the former should be degraded to a colony, or the latter to slaves; for otherwise it would have been a penal war, which is contradictory in itself."); id. at 138 ("Still less can Slavery be deduced as a rightful institution, from the conquest of a people in war; for this would assume that the war was of a punitive nature.").

96. Id. at 137.

97. Id. at $139(\$ 60)$. Note the similarity between Kant's resistance to a power to destroy the existence of a defeated foe and Jacob Howard's position in February 1865 that Southern states must eventually be restored to their earlier position. STS, supra note 1, at $36 \mathrm{n} .87$ and accompanying text.

98. Id.

99. I cannot resist including a fascinating tidbit about Kant's jus post bellum discussion that touches on the legality of secession. In the next section after the comments just quoted, Kant proposes a "Permanent Congress of Nations" that could establish a "real state of Peace." Id. at 139 (\$ 61) (emphasis added). Kant then makes a passing comment on the indissolubility of the American Union: "By such a Congress is here meant only a voluntary combination of different States that would be dissoluble at any time, and not such a union as is embodied in the United States of America, founded upon a political constitution, and therefore indissoluble." Id. at 140 (emphasis added). 
generally well-understood that the losers of a war had no right to have their surrender taken unquestioningly at face value. Proffered surrenders had to be accepted, and by the proper authority. Article 156 of the 1863 Lieber Code, for instance, noted that in receiving promises from surrendering soldiers or armies, a victor may decide "whether reliance can be placed upon such oaths." Even those Southerners who thought that the Article VI oath was enough must have seen that only a sincere Article VI oath would do the job. Such sincerity could only be judged, moreover, by some agent of the victorious North, rather than by surrendering former Confederates. Eric McKitrick's comprehensive history of the conflict between the President and Congress noted the consensus: "[E]veryone, including President Johnson, understood ... there had to be terms. The South would have to do things, and the North would have to say what they were." 100

The Joint Committee on Reconstruction's report rooted the delay in Southern representation squarely on the North's jus post bellum rights. The Union could demand "adequate guarantees against future treason and rebellion" and impose "such conditions as, in the opinion of Congress, the security of the country and its institutions may demand." 101 It was "madness and folly" to say that "conquered enemies have the right, and shall be permitted at their own pleasure and on their own terms, to participate in making laws for their conquerors." 102 Former Confederates were "entitled only by public law to such rights, privileges, and conditions as might be vouchsafed by the conqueror." 103

\section{Law}

The Supreme Court has repeatedly recognized the general right of victors to demand further post-war security. For instance, in 1871, the Court upheld a law that tolled statutes of limitations during the war, even after the surrenders of 1865 . The Court commented, "[T]he [war] power is not limited to victories in the field and the dispersion of the insurgent forces. It carries with it inherently the power to guard against the immediate renewal of the conflict and to remedy the evils which have arisen from its rise and progress." 104 This was not mere special

100. ERIC L. MCKITRICK, ANDREW JOHNSON AND RECONSTRUCTION 186 (1960); see also $i d$. at 23 (summarizing the consensus from earlier writers like Grotius: "[T]he victor needs to be assured that ... his objectives have been accomplished.").

101. REPORT OF THE JOINT COMMITTEE ON RECONSTRUCTION xx (1866).

102. Id.

103. Id. at xix

104. Stewart v. Kahn, 78 U.S. (11 Wall.) 493, 507 (1871). 
pleading during Reconstruction; cases after both World War $\mathrm{I}^{105}$ and World War $\mathrm{II}^{106}$ followed the same principle. The Court explained in 1947, "The cessation of hostilities does not necessarily end the war power.... [T] he war power ... is plainly adequate to deal with problems of law enforcement which arise during the period of hostilities, but do not cease with them." ${ }^{107}$ Security for the victors is a standard, uncontroverted element of current jus post bellum law. ${ }^{108}$ To be secure in one's victory is what it means to win a war, rather than to simply disperse opposing armies. The Fourteenth Amendment and Reconstruction Act are similar to demands regularly and legitimately made by victorious parties in armed conflict today:

Modern peace agreements regularly contain a large regulatory component, including numerous provisions on the organization of public authority and individual rights, such as provisions on transitional government, claims mechanisms, human rights clauses, provisions on demobilization, disarmament and reintegration, as well as provisions on individual accountability. ${ }^{109}$

Jus post bellum rules are a byproduct of the general need for the losers in a war to submit to the victors; therefore, they apply both to civil and international wars. As Jens David Ohlin recently remarked, Vattel coined the phrase "common law of war" to refer to "customary rules regarding warfare which applied during all armed conflictswhether they were classified as international or internal wars." 110 Stahn and Kleffner's recent study of jus post bellum likewise makes clear that

105. Hamilton v. Ky. Distilleries \& Warehouse Co., 251 U.S. 146, 161 (1919) (quoting same language from Stewart, "The power is not limited to victories in the field and the dispersion of the [insurgent] forces. It carries with it inherently the power to guard against the immediate renewal of the conflict, and to remedy the evils which have arisen from its rise and progress.").

106. Fleming v. Mohawk Wrecking \& Lumber Co., 331 U.S. 111, 116 (1947) (following Stewart and Hamilton, "The cessation of hostilities does not necessarily end the war power... that the war power includes the power to remedy the evils which have arisen from its rise and progress and continues during that emergency.").

107. $I d$.

108. See generally JUS POST BELLUM: TOWARDS A LAW OF TRANSITION FROM CONFLICT TO PEACE (Carsten Stahn \& Jann Kleffner eds., 2008) [hereinafter JPB].

109. Carsten Stahn, Jus post bellum: Mapping the Discipline(s), in JPB, supra note 108, at 100 .

110. Jens David Ohlin, The Common Law of War, 58 WM. \& MARY L. REV. 493, 499 (2016); see also id. at 518 ("[E]ven civil wars are governed by natural law through the common law of war"); id. at 518-19 (quoting the Prize Cases and Vattel, "[t]his being the case, it is very evident that the common laws of war-those maxims of humanity, moderation, and honour-ought to be observed by both parties in every civil war"). 
the general problem of security for the victor applies both to civil and international armed conflict. ${ }^{111}$

\section{THE SEPARATION OF WAR POWER}

Granted, then, that the victorious Union could delay Southern participation in the statutory and constitutional lawmaking processes until it thought it was safe, did the Union in fact do so? The first issue here is, who should count as "the Union" - the President or Congress? Secondly, did Congress act with enough clarity to suspend Article V powers, if it did not pass a resolution saying that the Amendment had been adopted with only loyal-state ratifications? I explain here why the war-declaration power puts Congress, not the President, in charge of end-of-wartime-suspension decisionmaking, and that Congress was not required to spell out the application to the Article $\mathrm{V}$ denominator in so many words.

\section{A. Congressional Power Over Wartime-Restriction Timing}

The first issue is the easier one: a congressional jus post bellum power to delay a condition of peace is the unavoidable corollary of a congressional jus ad bellum power to "declare War." 112 Even if the President has the power to repel sudden attacks or initiate hostilities, it is textually unavoidable that Congress can, on its own, "declare War." Maybe the President can too, ${ }^{113}$ but Congress has the power to declare that a state of war exists. And the jus post bellum power is simply this power set in a time frame: the power to say that a state of war still exists. Even if, for whatever reason, the condition of hostility does not amount to a "war," congressional power to call forth the militia to "suppress Insurrections"114 entails a power to set the criteria for when an insurrection exists. If Congress says one exists, it does, and if Congress says one still exists, it still does.

111. See Andre Nollkaemper \& Nico Schrijver, JPB, supra note 108, at v ("[T]he concept of jus post bellum ... has an established background in just war doctrine. But it has significant potential in its application to the situation following modern armed conflicts, irrespective whether of an interstate or intrastate nature."); Stahn, supra note 109, at 106 ("A jus post bellum would have to apply in the aftermath of civil wars.").

112. U.S. CONST. art. I., § 8, cl. 11.

113. Michael D. Ramsey, The Textual Limit on the President's War Powers, NAT'L CONSTITUTION CTR., https://goo.gl/TWpXFr (noting, though, there is a "widespread consensus that the Declare War Clause limits the President's power to initiate the use of military force").

114. U.S. CONST. art. I., $\$ 8$, cl. 15 . 
Vattel, in considering how the law of war might apply in different countries, noted this point: as a matter of logic and domestic law, the power to delay the end of a war is in the same hands as the power to begin a war. The power to "judge of the causes and reasons for which war is to be undertaken" entails the power "to point out the time when it shall be discontinued." 115 Grotius agreed: "They who have Power to begin a War, have likewise Power to enter upon a Treaty to finish it." 116 If the president has an independent power to decide that a state of war exists - perhaps because we have been suddenly attacked - he may also have the power to decide that such a condition persists. But whatever the President's powers, Congress certainly has the power to declare that the conditions of wartime still exist. Without congressional acquiescence, the president cannot-as Andrew Johnson hopeddeclare that the war is definitively over.

A treaty might also end a war, and so (two thirds of) the Senate together with the President could cut the House out of the peacedelaying process. ${ }^{117}$ Once peace had been re-established, Congress could declare a new war, but it could not continue the old one; its power would thus be subject to the jus ad bellum (the rules relating to going to war), not the jus post bellum (those relating to ending a war). No such treaty, though, ever ended the Civil War.

President Johnson did declare on August 20, 1866, that "the said insurrection is at an end and that peace, order, tranquility, and civil authority now exist in and throughout the whole of the United States of America." 118 He claimed that because peace was re-established, "that such constituent States must necessarily be, and by the Constitution and laws of the United States are made equals, and placed upon a like footing as to political rights, immunities, dignity and power with the several States with which they are united."119 Congress, however, disagreed, and its war-status-declaration power trumps the President's. One way to see the distinction is to use J.L. Austin's terminology: the congressional power to declare war is, like the power to say "with this ring I thee wed," or "I hereby promise," a performative use of language. Unlike most statements about reality, for

115. VATTEL, supra note 25 , at $655(4.2, \S 10)$.

116. 3 GROTIUS, supra note 50, at 1551 (\$ 3.20.2).

117. U.S. CONST. art. II $\S 2 \mathrm{cl} .2$ (stating presidential power to "make Treaties, provided two thirds of the Senators present concur").

118. Andrew Johnson, Proclamation No. 4, 14 Stat. 814, 817 (August 20, 1866).

119. Id. at 816 . 
Congress to simply say that a state of war exists is for Congress to make such a state of war exist (if it did not already). Presidential statements about peace and war, by contrast, are statements about an independently-existing reality, not constitutive elements of that reality itself: Austin would call them "constantive" uses of language. ${ }^{120}$

The only early source explicitly considering the extent of congressional and presidential powers to end wartime suspensions, William Rawle, makes clear that the President cannot restore rights suspended by war on his own. Rawle noted in 1825 that a presidential truce, though it could for the time being terminate "hostilities," cannot "revive treaties which were broken by the commencement of the war, or restore rights of any sort, which were suspended by it." ${ }^{121}$ Rawle's brief comment encapsulates almost the entire loyal-denominator argument: wartime agreement-suspension, the jus post bellum distinction between ending hostility and establishing peace, and the lack of presidential power outside the context of a treaty to exercise jus post bellum power.

\section{B. Did Congress Pull the Trigger?}

In addition to his arguments discussed above, ${ }^{122}$ Harrison has urged that Congress did not "pull the trigger." He elaborates:

Although the reduced denominator theory has merits, it is also subject to doubt. While many Republicans endorsed it to varying degrees, they still did not pull the trigger and proclaim the Fourteenth Amendment ratified by three-fourths of the represented states. Instead, they waited until three-fourths of all the states had, in their view at least, agreed to the Amendment. It seems that they were not prepared to try the more aggressive theory unless they absolutely had to. ${ }^{123}$

Harrison is right about the uneasiness of several Republicans; as documented at length in the companion to this Article, a few significant Republicans, most prominently Lincoln in his last public address and Senators John Sherman, Oliver Morton, and George Edmunds,

120. J. L. Austin, How to Do Things WiTh Words 25 (J. O. Urmson \& Marina Sbisà eds., $2 \mathrm{~d}$ ed. 1962) (performative utterance defined "as not, or not merely, saying something, but doing something, and as not a true or false report of something"); $i d$. at 3 ("true or false statements" deemed "constative").

121. William Rawle, A View of the Constitution of the United States of AMERICA 110 (2d ed. 1829).

122. See supra notes $11,29,32$, and 34 and accompanying text.

123. Harrison, supra note 5, at 422 (emphasis added). 
professed agnosticism about the size of the Article $\mathrm{V}$ denominator, though many more Republicans explicitly advocated a loyal denominator. ${ }^{124}$ Agnosticism is only the rejection of a loyal denominator if a loyal denominator required specific Congressional action. But Congress had no special power to "proclaim the Fourteenth Amendment ratified." There was no trigger to pull.

Article $\mathrm{V}$ is clear on the timing of new amendments, and Congress is simply not involved: proposals "shall be valid to all Intents and Purposes, as Part of this Constitution, when ratified . . . ."125 Congressional power to say that the Amendment was ratified, like the President's power to say that the nation was now at peace, is not the power to make it so. ${ }^{126}$ As Michael Stokes Paulsen puts it, "nothing in the text of Article V remotely suggests ... a substantive commitment" of amendment-validity issues to Congress. ${ }^{127}$ Neither Congress in July 1868 , nor Secretary of State Seward in his proclamations about the Thirteenth and Fourteenth Amendments, claimed the right to conclusively resolve the ratification-legitimacy issue for everyone. ${ }^{128}$ Three days after the loyal-denominator threshold was passed, Reverdy Johnson rightly told Republicans who were considering a resolution declaring the Fourteenth Amendment to already be the law that others might disagree with it:

When will the Constitution be amended by the ratification of three fourths of those States that are represented? Who is to decide that?

124. See STS, supra note 1, at $37 \mathrm{n} .95,62 \mathrm{nn} .236-38$ and accompanying text.

125. U.S. CONST. art. V.

126. See J.L. Austin, supra note 120 (defining performative utterance "as not, or not merely, saying something, but doing something, and as not a true or false report of something").

127. Michael Stokes Paulsen, A General Theory of Article V: The Constitutional Lessons of the Twenty-Seventh Amendment, 103 YALE L.J. 677, 707 (1993). Paulsen compellingly takes down the contrary reasoning of two separate opinions in Coleman v. Miller, 307 U.S. 433 (1939) - Chief Justice Hughes's statement that Congress has "control over the promulgation of the adoption of the amendment," $i d$. at 450, and Justice Black's view that "Congress has sole and complete control over the amending process," $i d$. at 459 . Paulsen also notes that many earlier cases had adjudicated challenges to amendments without taking Congress's word on the issue as in any way binding; see $i d$. at 712 n.123 (citing United States v. Sprague, 282 U.S. 716 (1931) (answering an attack on 18th Amendment); Leser v. Garnett, 258 U.S. 130 (1922) (answering an attack on 19th Amendment); National Prohibition Cases, 253 U.S. 350 (1920) (answering an attack on 18th Amendment); Hawke v. Smith, 253 U.S. 231 (1920) (answering an attack on 19th Amendment); Hawke v. Smith, 253 U.S. 221 (1920) (answering attack on $18^{\text {th }}$ Amendment); and Hollingsworth v. Virginia, 3 U.S. (3 Dall.) 378 (1798) (answering an attack on 11th Amendment).

128. Paulsen, supra note 127, at 712 ("[I]f the views of Seward and Congress in 1868 count as precedent, they should be precedent as to the merits of the specific issues there addressed, not for the proposition that the decision is committed to the political branches-still less to Congress in particular. Neither Congress in its proclamations nor Seward in his made any such grandiose assertion."). 
That is an open question, and must be an open question just as much after you have declared that it is to be a part of the Constitution when ratified by three fourths as if you leave it blank. If in point of law the States that are now represented are the States to whom it is to be referred and by whom is to be ratified the constitutional amendment proposed by Congress, then the Constitution of the United States will be altered in that respect; but if it is to be submitted to more than the States that are represented in Congress, that is to say, to all the States, the question will be open whether Congress declares it or not .... ${ }^{129}$

In short, Congress did not have the power, simply by saying so, to alter the Article $\mathrm{V}$ denominator, either to make it smaller or to make it larger. Congress had the power under the war-declaration ${ }^{130}$ and insurrection-suppression ${ }^{131}$ powers to recognize the continuing hostility of the South, and a reduced Article $\mathrm{V}$ denominator followed from that recognition. There is no separate amendment-recognizing power, however, that Congress failed to deploy - no critical un-pulled trigger.

Further, cases after the war that consider whether particular rights of Confederate states were suspended during the war do not consider whether Congress specifically declared those particular rights to be suspended. Texas $v$. White held in 1869 that the right to sell bonds was suspended, ${ }^{132}$ while White v. Hart held in 1872 that the duty not to impair the obligation of contracts was not suspended. ${ }^{133}$ Suspension of rights followed as a matter of law from the (congressionallyrecognized) state of war itself.

Congress was clear in both July 1866 and March 1867 that, as far as it was concerned, the South was still in a state of hostility, and that it was exercising the Union's jus post bellum/jus victoriae rights to delay a legally-operative state of peace. In the statute readmitting Tennessee in 1866, Congress declared that a "State government can only be restored to its former political relations in the Union by the consent of the law-making power of the United States."134 "Political relations in the Union" is a broader concept than simply "representation in

129. CONG. GlobE, 39th Cong., 2d Sess. 1393 (February 15, 1867) (emphasis added).

130. U.S. CONST. art. I, § 8, cl. 11.

131. U.S. CONST. art. I, § 8, cl. 15 .

132. Texas v. White, 74 U.S. (7 Wall.) 700, 727 (1869); see also Thomas v. Richmond, 79 U.S. (12 Wall.) 349, 357 (1871); Hanauer v. Doane, 79 U.S. (12 Wall.) 342, 345 (1871).

133. White v. Hart, 80 U.S. (13 Wall.) 646, 651 (1872); see also Gunn v. Barry, 82 U.S. (15 Wall.) 610, 623 (1873); Keith v. Clark, 97 U.S. 454, 461 (1878).

134. Joint Resolution Restoring Tennessee to her Relations to the Union, 14 Stat. 364 (1866). 
Congress," and includes articles I, II, and V. ${ }^{135}$ The statute concluded, "the State of Tennessee is hereby restored to her former proper, practical relations to the Union, and is again entitled to be represented by senators and representatives in Congress." 136 Congress thereby declared that peace under the law was re-established between the Union and Tennessee. But Congress's explicit insistence on affirmative congressional consent, plus silence regarding other states, made clear that a legal peace was re-established only in Tennessee.

The Reconstruction Act of March 1867 also made this clear: the governments of the "rebel States" were "provisional only, and in all respects subject to the paramount authority of the United States at any time to abolish, modify, control, or supersede the same." 137 By making it very plain that the South was still under wartime legal disabilities, Congress pulled the still-at-war-declaration trigger quite straightforwardly. Johnson's veto of the Reconstruction Act also makes clear the hinge on which the legitimacy turned: whether 1867 should be deemed "a time of peace." 138 In the Reconstruction Act, Congress - the branch with explicit power to decide the division between wartime and peacetime-said no.

Finally, even if, as Amar contends, ${ }^{139}$ the process of reconstruction during 1867 and 1868 is construed as genuine Southern part-authorship of the Fourteenth Amendment, coercion in that process must be evaluated against the baseline of what Congress would have been allowed to do legally. Congress told states that they would only be admitted to Congress if they agreed to the Fourteenth Amendment. ${ }^{140}$ As explained below, this is rightly seen as impairing the pretension of free, unforced "reflection and choice" in our processes of constitutional adoption that Americans have made since the Founding. But if Congress had the power to declare the Fourteenth Amendment law under a loyal-denominator theory, then the threatened alternative was no worse (on this score) than what Congress asked former

135. See id.

136. Id. (emphasis added).

137. An Act to Provide for the More Efficient Government of the Rebel States, 14 Stat. 428, $429 \S 6$ (1867).

138. CONG. Globe, 39th Cong., 2d Sess. 1730 (1867).

139. See AKhil Amar, AmericA's Unwritten Constitution: The Precedents AND PRINCIPLES WE LIVE BY 87 (2012) ("[Congress] ultimately opted to include ex-Confederate states in the amendment process.").

140. See 14 Stat. at $429 \S 5$ (An act responding to the difficulties of loyalists trying to vote, that provided that military authorities conduct elections for the state constitutional convention pursuant to basic reconstruction laws). 
Confederates to do themselves. As Mitch Berman has noted, a relatively stable scholarly consensus has emerged around the idea that "a conditional proposal is coercive if it would be wrongful for the maker to do as it threatens." lawfulness of hypothetical Congressional action actually imposing a loyal denominator is essential to deciding whether the invitation to the South to ratify "on its own" was improperly coercive. A far cleaner interpretation of Congress's action was simply that the Fourteenth Amendment actually was the law, so that the Reconstruction Act should not be seen as a conditional threat at all. But even if the Reconstruction Act was a conditional threat, it avoids improper coercion only if the loyal-denominator theory could have been proper.

\section{IMPLICATIONS}

Aside from any change to the constitutional author, loyal denominatorism can also help lay to rest any embarrassment with the Fourteenth Amendment's provenance that might otherwise hinder its energetic enforcement. This Section briefly considers four other implications of seeing the Fourteenth Amendment as authored only by the loyal North. The change is important both for our understanding of the nature of the Constitution's status as an act of self-government and for our understanding of how the Constitution should be interpreted.

\section{A. Avoiding Ackerman, Amar, Colby, and Harrison's Lessons: Preserving Government by "Reflection and Choice"}

Loyal denominatorism can rebut the practical implications of alternative theories: that is, help resist Ackerman's non-Article-V amendment power, Harrison's hyperformalism, Amar's general federal power over state suffrage rules, and Colby's non-originalism. ${ }^{142}$ The victorious, loyal North reflected, free of coercion, on whether to adopt the Fourteenth Amendment; it was a product of federally-structured "reflection and choice" rather than "accident and force," in Hamilton's words. ${ }^{143}$

141. See Mitchel N. Berman, Coercion, Compulsion, and the Medicaid Expansion: A Study in Unconstitutional Conditions, 91 TEX. L. REV. 1283, 1347 (2013) ("Normative theorists have coalesced around [this view].”).

142. See supra notes 3-8, and accompanying text; STS, supra note 1, at 16-17 nn.22-25 and accompanying text.

143. Hamilton et al., supra note 24 , at 1 ("It has been frequently remarked that it seems to have been reserved to the people of this country, by their conduct and example, to decide the important question, whether societies of men are really capable or not of establishing good 
Excluding the South from constitutional co-authorship while it was subject to the Reconstruction Act thus improves the legitimacy and integrity of the constitutional author. States subject to total federal control in section 6 of the Reconstruction Act, ${ }^{144}$ as well as the martial law in sections 1 through 4 , are not the free agents who can legitimately be taken to be authors of a Constitution based on "reflection and choice" rather than "force." Blackstone explained property requirements for suffrage in terms of subjecting the poor to others' wills:

The true reason of requiring any qualification, with regard to property, in voters, is to exclude such persons as are in so mean a situation that they are esteemed to have no will of their own.... Only such are entirely excluded [from the suffrage], as can have no will of their own: there is hardly a free agent to be found, but what is entitled to vote in some place or other in the kingdom. ${ }^{145}$

Thus, suffrage entails freedom, and the "provisional only" governments of the South were not free. Loyal denominatorism, on the other hand, justifies the Reconstruction Act's imposition of Fourteenth Amendment on the South very simply: the Fourteenth Amendment was already the law, not an act in which Congress was inviting the South to participate as a forced co-author. If the South was an unwilling coauthor, the Fourteenth Amendment becomes a partly insincere act of capitulation, rather than a legitimate demand. Unqualified legitimacy for the Amendment requires a genuine expression of sovereign will. But as Blackstone explains, such a genuine expression requires unqualified freedom in its author, and only the North possessed such freedom during Reconstruction. If coerced ratifications are the only possible justification for the Fourteenth Amendment, we might have to accept them, ${ }^{146}$ but loyal denominatorism offers another way.

government from reflection and choice, or whether they are forever destined to depend for their political constitutions on accident and force."). For the federally-structured aspect, see id. at 196 (Madison in Federalist 39) and infra note 154 and accompanying text.

144. 14 Stat. at 429 ("[U]ntil the people of said rebel States shall be by law admitted to representation in the Congress of the United States," Southern government "shall be deemed provisional only, and in all respects subject to the paramount authority of the United States to abolish, modify, control, or supersede the same" until their representatives are admitted to Congress).

145. 1 William Blackstone, COMMENTARIES *170 (emphasis added).

146. See Harrison, supra note 5, at 457 (arguing that former-Confederate ratifications may have been coerced, but that under principles of international law, this does not invalidate the Fourteenth Amendment). 


\section{B. Jus post bellum, Southern Intransigence, and Lessons for Democratic Theory}

Reorienting our understanding of the Fourteenth Amendment to see that it became law before the Reconstruction Act, rather than because of it, does not eliminate the Act's coercion of the South. However, a jus post bellum frame better justifies such coercion. Amar ${ }^{147}$ and Ackerman ${ }^{148}$ are right to this extent: it is wrong to see the Fourteenth Amendment's enactment as the expression of "equal sovereignty," an idea the Court invoked incessantly in Shelby County v. Holder. ${ }^{149}$ Justice Black's dissent in South Carolina v. Katzenbach accused Congress of treating the South in the Voting Rights Act as "little more than conquered provinces." ${ }^{50}$ Rather than shying away from the charge, we should see Southern resistance to the principles of the Fourteenth Amendment (and the Fifteenth Amendment) as exactly the same sort of struggle that appears in every jus post bellum problem following armed conflict. ${ }^{151}$ The South is more than a set of conquered provinces, but it is not less. This is not to say that jus post bellum problems have easy solutions. Instead, we must be patient and persevering in pressing for the enforcement of the Fourteenth Amendment's principles despite Southern recalcitrance.

A stress on the coercion of the South involved in the Fourteenth Amendment and seeing jus post bellum principles as its justification might, however, be seen to make its troubles from the standpoint of democratic legitimacy even worse. If the northern-denominator Fourteenth Amendment is the act only of the North and not the whole nation, is it really an exercise in self-government of the sort our Constitution claims to be? The self-government question raises the issues with which Colby's consideration of the Fourteenth Amendment is chiefly concerned. His assessment of the Fourteenth Amendment focuses chiefly on the question of democratic pedigree, as opposed to

147. See Amar, The Lawfulness of Section 5, supra note 7, at 109.

148. See 3 Bruce Ackerman, We the People: The Civil Rights Revolution 403-04 (President and Fellows of Harvard College, 2014) (criticizing Shelby County's use of precedent, especially Texas v. White, 74 U.S. (7 Wall.) 700 (1869), which held that actions taken by Texas in support of the rebellion, such as the sale of bonds, were null and void).

149. See generally Shelby County v. Holder, 133 S.Ct. 2612 (2013). References to "equal sovereignty" appear on almost every page of the relatively-short opinion. See id. at 2618, 2621, $2622,2623,2624$, and 2630. Note the similarity to President Johnson's view of the South. Cf. supra note 119 and accompanying text.

150. South Carolina v. Katzenbach, 383 U.S. 301, 360 (1966) (Black, J., dissenting).

151. See generally JPB, supra note 108 (reflecting on jus post bellum and the dynamic processes and structures involved in moving from conflict to peace). 
legal legitimacy as such. His chief objection to the loyal denominator lies not in technical issues regarding the interpretation of "three fourths of the several States" in Article V, but on whether the Fourteenth Amendment can be seen as a genuine exercise of popular sovereignty. His democratic argument against the loyal denominator on that basis is very simple: "One cannot demonstrate that a constitutional amendment reflects a supermajoritarian consensus among the people simply by excluding from the equation the people of the states that rejected it." 152

The loyal denominator theory, however, does not exclude the Southern states from the constitutional author simply because they rejected the Fourteenth Amendment; the theory excludes them from the power of constitutional authorship because they illegally seceded. Is a secession-based definition of "the people," then, democratically legitimate? Colby evidently thinks not. We should avoid overconfidence about the principles that govern democratic legitimacy, but that question can be paired with another: is the distinction between states and territories democratically legitimate? While most advocates of the loyal Article $\mathrm{V}$ denominator held that former Confederate states were still states, and not literally reduced to the status of territories, these advocates still repeatedly used territorial metaphors to describe the condition of the South. ${ }^{153}$ Those who venture out into the lesspopulated parts of a country are still, one might think, part of "the

152. Colby, supra note 8 , at 1682 .

153. See STS, supra note 1, at 35 (citing Cong. Globe, 38th Cong., 2d Sess. 533, 554) (Senator Jacob Howard) ("[T]he United States . . have the same power and authority over the conquered States .... as the nation itself would possess over foreign territory conquered in the same way.... [T] [Te power of the United States over a conquered State which has been in rebellion is the ordinary power of the conqueror over conquered territory."); id. at 78 (citing CONG. GloBE, 39th Cong., 2d Sess. app. 89) (Representative Ebon Ingersoll) ("The late rebel States are to all intents and purposes as much territories of the United States, subject to the exclusive control of Congress, as are the territories of Utah, New Mexico, Montana, or any other Territory belonging to the Government."); id. at 83 (New York Times stating that the loyal denominator "implies the reduction of the now excluded States to something resembling a territorial condition."), id. at 88 (citing New York Herald editorial, The Work Before the Reconstruction Committee - The Right Way to Do It, 2 (February 1, 1867)) ("The duty will then devolve upon Congress of proclaiming the amendment part and parcel of the Federal Constitution, the supreme law of the land, binding alike upon the inside and outside States and the Territories."); id. at 93 (citing ISRAEL WARD ANDREWS, MANUAL OF THE CONSTITUTION OF THE UNITED STATES 253-54 (1874)) ("A proposed Amendment to the Constitution is no more dependent on the assent of a State holding such relation to the nation, than upon that of a Territory."); id. at 93 (citing J.W. BuRGESS, RECONSTRUCTION AND THE CONSTITUTION 1866187681 (1902)) (under the loyal-denominator view, "their [Southern states'] petition for admission or recognition as 'States' of the Union with the amended Constitution would imply their assent to the Amendment as well as to every other part of the Constitution”). 
people," but they are denied federal political authority until they achieve - and Congress allows - statehood. Is that legitimate? To prefer loyal states over once-rebellious ones now seeking readmission to the Union's political structures is no less democratically legitimate than preferring states already in the Union over those seeking admission to those structures for the first time.

The distinctively democratic legitimacy of a Northern-authored Fourteenth Amendment or a Constitution imposed by earlier states on later ones as the price of statehood depends on whether and how "the people" may be structured. James Madison referred to one type of structure as "the people" in Federalist 39: "[T]his assent and ratification is to be given by the people, not as individuals composing one entire nation, but as composing the distinct and independent States to which they respectively belong." 154 Reconstruction and the privileging of earlier states over territories impose another sort of structure on our popular sovereign. Those lying on one side of certain geographic, temporal, or domestic-insurrectionary boundaries, the story would go, legitimately have different powers than those on the other side. Established states have been around, loyally supporting the structures of the Union, longer than territorial entities; former Confederate states whose loyalty is subject to question are likewise properly seen as junior partners relative to states that stuck with the Union.

These temporal metaphors suggest that secession means forfeiting seniority. That is, the relationships of North to South and States to Territories are strongly akin to the relationship of Generation 1 to Generation 2. The authority of those now dead to set rules for the living is itself a difficult problem for democratic theory, but a tripartite analogy - North : South :: Established States :Territories :: Generation 1 : Generation 2-may help us think about all three problems. I will consider the analogy more fully in future work, but will give a brief sketch here.

Importantly, the Constitution was not imposed on the South, or on Territories, or on prospective officials today, utterly without their consent. The South was told to ratify the Fourteenth Amendment, as a pledge of loyalty, ${ }^{155}$ if they wanted to be represented in Congress. Those

154. Hamilton et al., supra note 24 , at 196.

155. See STS, supra note 1, at 46 n.138 (listing a great many Republicans who construed Southern ratifications as pledges of loyalty, rather than as constitutional co-authorship). 
in territories are told to agree to the Constitution if they want to be in the Union. ${ }^{156}$ The current generation is told (by Article VI's oath requirement) to be bound to support the Constitution if they want to be officials. ${ }^{157}$ These acts of consent may not amount to the sort of selfgovernment that can legitimate Reconstruction, the lessened federal rights of those living in territories, or the intergenerationally-imposed Constitution in the eyes of our preferred democratic theory. But it might be possible to understand the obligations of those who have agreed to such impositions, even while we bracket the issue of the political principles that should govern the propriety of state-toterritory, North-to-South, or intergenerational assertions of authority themselves.

A first normative consideration is the "mind of the imposer" or animus imponentis tradition in oath interpretation, which governs the obligations of those taking oaths as conditions imposed by others. ${ }^{158}$ Those oaths must be governed, the tradition says, according to the way its words would be understood by the one imposing the oath, rather than according to any possible mental reservations in the mind of the one agreeing to the oath (the "animus jurantis").

As applied to Reconstruction, the upshot would be that by taking the offer in the Reconstruction Acts and approving the Fourteenth Amendment, the South was agreeing to be bound, not by their own understandings of its language, but by that of the imposing power, the North. This is true even if the Reconstruction Acts breached some sorts of norms of democratic self-government. As applied to the intergenerational assertions of authority at stake in the dead hand problem, the result is a form of originalism that can sidestep the

156. See, e.g., Eric Biber, The Price of Admission: Causes, Effects, and Patterns of Conditions Imposed on States Entering the Union, 46 AM. J. LEG. HIST. 119, 119-20 (2004).

157. See U.S. CONST. art. VI, cl. 3 ("The Senators and Representatives before mentioned, and the Members of the several State Legislatures, and all executive and judicial Officers, both of the United States and of the several States, shall be bound by Oath or Affirmation, to support this Constitution ....”); see also AID v. All. for Open Soc'y, 133 S. Ct. 2321, 2335 (2013) (Scalia, J., dissenting) (arguing that citizens are free to hold political views contrary to that of the Constitution, such as communism or anarchism, but Article VI wisely imposes "affirmative ideological commitments prerequisite to assisting in the government's work").

158. See, e.g., William PALEy, The PRINCIPLES OF MORAL AND POLITICAL PHILOSOPHY 111 (\$3.2.16.6) (2002) (1785) ("As oaths are designed for the security of the imposer, it is manifest that they must be interpreted and performed in the sense in which the imposer intends them; otherwise, they afford no security to him. And this is the meaning of the rule, jurare in animum imponentis'...."); id. at 119 (\$ 3.2.21) ("The animus imponentis . . . is the measure of the juror's [i.e., oath-swearer's] duty. The inquiry, therefore, concerning subscription will be, quis imposuit, et quo animo? [Who imposed it, and with what intention?]"). 
normative attacks of the dead hand. Even if the founders breached norms of self-government in requiring later generations to swear the Article VI oath, those who swear it are nonetheless bound to obey it as its text would be understood from the imposer's perspective, i.e., according to its original meaning.

A second source of insight is an analogy to the assertion of in rem jurisdiction by a court: authority over a thing, rather than authority over persons (i.e., in personam jurisdiction). Litigants who want to assert a claim in the thing must agree to abide by the court's rulings, independent of any authority the court might otherwise have to issue judgments binding on those litigants; "all the world" is bound in virtue of the court's control over the res. ${ }^{159}$ The theory of in rem jurisdiction, however, is that we can decide whether a court has authority over a particular thing without having to resolve, on the basis of otherwiseapplicable in personam personal-jurisdiction rules, whether the court would have authority over all of the particular people in the world who might claim an interest in the object. Authority over the object is enough. If the founding generation, or the North, or pre-existing states, are legitimately in control of the federal government, then they can exercise authority over that government in a way that will legitimately bind everyone in the world who wants to take part in it-later generations, the South, or those in territories seeking to become states.

A third source of guidance is an analogy to the shrink-wrap contract. Under cases like ProCD v. Zeidenberg ${ }^{160}$ and Hill v. Gateway $2000,{ }^{161}$ purchasers who accept a license as part of the price of obtaining a product are bound by that license's terms, even if the purchaser never reads it and there is therefore no "meeting of the minds" of the contracting parties. The contract written by the seller, and to which the buyer is given access, governs according to its terms, even though the

159. See, e.g., Mankin v. Chandler, 16 F. Cas. 625, 626 (E.D. Va. 1823) (Marshall, J.) ("[W]here the process is to be served on the thing itself, and where the mere possession of the thing itself, by the service of the process and making proclamation, authorizes the court to decide upon it without notice to any individual whatever, it is a proceeding in rem, to which all the world are parties."); Dulin v. McCaw, 20 S.E. 681, 684 (W.Va. 1894) (“A proceeding in rem is a judicial proceeding against the thing itself, which, terminating in a valid judgment, binds all the world.").

160. See ProCD v. Zeidenberg, 86 F.3d 1447, 1448-49 (7th Cir. 1996) (stating that Shrinkwrap licenses are enforceable as soon as the buyer tears the wrapping of the package, even if they are printed on the outside of the box).

161. See Hill v. Gateway 2000, 105 F.3d 1147, 1148-49 (7th Cir. 2000) (holding that in a situation where the terms of a product sent in a box to a buyer stated that they governed the sale, unless the item was returned within 30 days, bound the buyer who failed to return the product, because contracts do not need to be read to be effective, and those who fail to read the terms assume the risk of those terms being unfavorable). 
seller is almost certainly the only one who has considered all of its language. The founders, the North, and existing states are entitled to shrink-wrap the federal government with the Article VI oath, binding anyone who wants access to it.

Fourth, consider an analogy between the past and a foreign country. "The past is a different country; they do things differently there." 162 "[E]ach new generation born is in effect an invasion of civilization by little barbarians, who must be civilized before it is too late." ${ }^{163}$ Noah Webster claimed that intergenerational constitutional assertions of authority were as illegitimate as one nation telling another what to do: "[T] he very attempt to make perpetual constitutions, is the assumption of a right to control the opinions of future generations; and to legislate for those over whom we have as little authority as we have over a nation in Asia." ${ }^{164}$ But if the past is a different country, then future generations of officials are immigrants, without any particular right to claim a share of past generations' resources. If this analogy is right, then naturalization and Article VI oaths are on a moral par.

This quick sketch makes a great many unstated and challengeable assumptions, but I hope to make them explicit and defend them in the future. In short, like Ackerman, Harrison, Amar, and Colby, I use the Fourteenth Amendment as my own favorable precedent. The imposition of the Fourteenth Amendment on a South was rightly seen by many of those favoring the loyal denominator as closely analogous to the imposition of the Constitution on new states formed out of the territories, which is itself closely analogous to the imposition of the Constitution on later generations. If this three-fold analogy is proper, and if we think the South was obliged to obey a Northern-authored Fourteenth Amendment, we can generalize the normative lesson. Like the former Confederates, new states and later generations were not given the chance to vote on the Constitution as it then stood; participation in the federal Union and taking offices governed by Article VI mean submitting to its Constitution on a take-it-or-leave-it

162. L.P. HARTLEY, THE GO-BETWEEN 5 (1953).

163. Thomas Sowell, A CONFlict of Visions: IdeOlogicAl ORIGINS OF POLITICAL STRUGGLES 167 (2007). Others attribute the same idea to Hannah Arendt. E.g., Jonah Goldberg, Western Civilization and Other Fairy Tales, NATIONALREVIEW.COM, https://goo.gl/sDArf7 ("Political theorist Hannah Arendt once said that, every generation, Western civilization is invaded by barbarians-we call them "children."”).

164. Gordon S. WOOD, THE CREATION OF THE AMERICAN REPUBLIC, 1776-1787 379 (2d ed., 1983) (citing Giles Hickory (pseudonym for Noah Webster), On the Absurdity of a Bill of Rights, AMERICAN MAGAZINE (Dec. 1787)). 
basis. Having taken the offer, however, the South, new states, and later generations swearing the Article VI oath are all obliged to obey the Constitution according to its terms, as those terms were understood by those in the Union before, imposing it on new entrants-i.e., as it was understood by the North, by earlier states, and by the founding generation.

\section{The Importance of Context in Interpretation}

A third implication of loyal denominatorism is a fuller appreciation of the role of larger linguistic context in supplying tacit limits to the scope of terms like "the several States" or "each State" in the Constitution. Facially, these texts seem to apply even during war, but context supplies an implicit peacetime limit. Jonathan Gienapp has recently complained that originalists' interpretive method is "narrow and atomistic," rather than appreciating the way in which "individual utterances earn their meaning based on how they fit into a linguistic whole." 165 The importance of context-sensitive tacit quantifier domain restrictions can serve as a partial antidote to the atomism and contextinsensitivity that Gienapp sees in originalism. Such atomism is not essential to originalism. Only the context in which a text is embedded tells us what domain it is intended to cover. ${ }^{166}$

165. Jonathan Gienapp, Historicism and Holism: Failures of Originalist Translation, 84 FORDHAM L. REV. 935, 936 (2015) ("By failing to historicize the American Founding, their method of translation proceeds from the faulty premise that the Founding generation and we today occupy more or less the same linguistic world, an assumption that enables their translation to take a narrow and atomistic form. Accordingly, as a result of this failure to historicize, they fail to appreciate the holistic character of meaning - that individual utterances earn their meaning based on how they fit into a linguistic whole-and, accordingly, target the wrong object of interpretation, focusing on individual words and statements when they must first grasp the broader idioms from which those component parts issued.").

166. Gottlob Frege's philosophy of language similarly stresses the need for larger linguistic context: "[I]t is only in the context of a proposition that words have any meaning." GOTTLOB FREGE, THE FOUNDATIONS OF ARITHMETIC 73 (§ 62) (Oxford, Blackwell ed. 1950) (1884) (the Grundlagen) ("Nur im Zusammenhang eines Satzes bedeuten die Wörter etwas."); see also id. at 71-72 (\$ 60) ("[W]e ought always to keep before our eyes a complete proposition. Only in a proposition have the words really a meaning."); id. at $116(\$ 106)$ ("[W]e must never try to define the meaning of a word in isolation, but only as it is used in the context of a proposition."). For Frege's sense-reference distinction, see generally Christopher R. Green, Originalism and the Sense-Reference Distinction, 50 ST. LOUIS U. L.J. 555 (2006); Frege's context principle is also worth attention from legal scholars. 


\section{Implications of Northern Authorship for the Fourteenth Amendment's Meaning}

Loyal denominatorism changes the constitutional author from the traditional entire 37-state nation to the rump 26 states taking part in the federal government in February 1867. Therefore, the text of the Amendment should be read through the lens of Northern views of equality, due process, and the privileges of citizens, not as if the Amendment was genuinely co-authored with the South. An English sentence today would be interpreted slightly differently if we thought it were written by someone in England or Australia rather than America, or by a committee with members spread out among different English-speaking countries. Analogously, we should focus on the resonance of the Fourteenth Amendment text with Northern legal ideas, not those that could span both North and South. To the extent they differ from their Southern counterparts, Northern notions of equality, civil liberty, and due process are the Fourteenth Amendment's interpretive key. ${ }^{167}$

There are some reasons to think that the North and South spoke different legal languages during Reconstruction.

First, the background principles and practices that informed the Fourteenth Amendment's requirement of equality ${ }^{168}$ were very different in the North and the South. Brown v. Board of Education, for instance, shied away from historical grounds in part because of the history of segregated education-and lack of education-in the

167. For a few Republicans who described the Fourteenth Amendment as the export of Northern civil liberties to the South, see, e.g., SPEECHES OF THE CAMPAIGN OF 1866: IN THE STATES OF OHIO, KENTUCKY AND INDIANA 20 (1866) (speech of Benjamin Butler, August 25) (stating that the Fourteenth Amendment demands "that any one shall walk in peace in South Carolina the same as a citizen of South Carolina can now walk in Massachusetts"); id. at 41 (speech of Franz Sigel, September 27) ("There will be no peace, no prosperity, till every man, white or black - as I see here a black face before me-shall be as safe in this whole country, not only in the North, but in the South."); American Gazette, September 28, 1866, quoted in EDWARD McPherson, Proposed Fourteenth Amendment Of The United States 23 (1868) ("[W]hat this amendment does secure is the right of northern men, white or black, to enjoy, in any southern State to which business or pleasure may take them, the same immunity from outrage that is afforded her in the free north.").

168. See generally Green, supra note 45 (arguing that the Privileges or Immunities Clause requires equal citizenship). The Supreme Court has housed this equality requirement in the Equal Protection Clause, but there is good reason to house it instead in the Privileges or Immunities Clause, because "protection of the laws" was a well-understood term referring to literal protection from violence and the right to a remedy. See generally Christopher R. Green, The Original Sense of the (Equal) Protection Clause: Pre-Enactment History, 19 GEO. MAson U. CIV. RTS. L.J. 1 (2008); Christopher R. Green, The Original Sense of the (Equal) Protection Clause: Subsequent History and Application, 19 GEO. MASON U. CIV. RTS. L.J. 219 (2009). 
South. ${ }^{169}$ The history of segregation and education in the North, while far from exemplary, was very different, ${ }^{170}$ and this difference matters if the Fourteenth Amendment expressed Northern principles, rather than principles of the full nation.

Second, to the extent that rights prevalent in the Union at the precise time the Fourteenth Amendment was adopted have special claim to count as "privileges ... of citizens of the United States," 171 it matters if the North alone was fully represented in the Union at the time. The continuously-loyal states and those of the former Confederacy had different traditions of civil liberty. Steven Calabresi and Sarah Agudo point out some regional differences in the privileges generally accorded to citizens in different regions of the country in 1868. ${ }^{172}$ One particularly striking instance is the right to keep and bear arms. In incorporating the Second Amendment into the Fourteenth, McDonald v. Chicago relies on the fact that "a clear majority of the States in $1868 "-22$ of 37 -recognized such rights in their constitutions. ${ }^{173}$ However, "protection of gun rights was particularly

169. See, e.g., Brown v. Board of Education, 347 U.S. 483, 489, 489 n.4 (1954) (explaining some regional differences in education between the North and South, noting much slower development in South).

170. See, e.g., Michael W. McConnell, Originalism and the Desegregation Decisions, 81 VA. L. REV. 947, 962 (1995) ("[T] he first attacks on racially segregated education occurred at the state level, in both the South and the North. Developments in the two regions, however, were so different that they must be considered separately."); $i d$. at 977 ("The experience in the Northern states during the fifteen-year period after ratification of the Fourteenth Amendment thus falls short of proving that school segregation was understood to violate the Amendment, but it is also inconsistent with the equally extreme view that the Amendment had no bearing on the issue .... As the implications of the new constitutional regime came to be more fully understood in the North, segregation eventually was prohibited, either by legislative or judicial action, in every state.").

171. See Josh Blackman \& Ilya Shapiro, Opening Pandora's Box? Privileges or Immunities, the Constitution in 2020, and Properly Incorporating the Second Amendment, 8 GEO. J.L. \& PUB. POL'Y 1, 8 (2010) (placing focus on "how privileges or immunities were understood in 1868"); id. at 70 (accepting my earlier characterization that such a view would "freeze the privileges of citizens of the United States in 1868 amber"); see also Christopher R. Green, McDonald v. Chicago, the Meaning-Application Distinction, and "Of" in the Privileges or Immunities Clause, 11 ENGAGE NO. 1, 24, 26 (Mar. 2010) (explaining different interpretations of the Privileges and Immunities Clause).

172. See Steven Calabresi \& Sarah Agudo, Individual Rights under State Constitutions when the Fourteenth Amendment was Ratified in 1868: What Rights are Deeply Rooted in the American History and Tradition?, 87 TEX. L. REV. 7, 29-30 (2008) (showing charts displaying regional trends for various constitutional rights, defining "South" as the former slave states minus Delaware). Of course, to produce data most relevant to my view of the Fourteenth Amendment author, the 1868 should be 1867, and "South" should be defined more narrowly (i.e., excluding Tennessee, Missouri, Kentucky, and Maryland).

173. McDonald v. Chicago, 561 U.S. 742, 777 (2010) (relying on Calabresi \& Agudo, supra note 172 , at 50$)$. 
Southern as long ago as 1868." ${ }^{174}$ Because 13 of the 15 states lacking state-constitutional rights to keep and bear arms were in the North (including Nebraska), the 22-to-15 majority slims down to 14-12 if only those states represented in Congress at the exact moment of the Fourteenth Amendment's adoption in February 1867 are considered (the majority shrinks further, to 14-13, if Nebraska, admitted on March 1,1867 , is included too). ${ }^{175}$ There was therefore no national stateconstitutional consensus in favor of gun rights at the Fourteenth Amendment's precise time of adoption. To be sure, I disagree with McDonald about whether the prevalence of rights at the time of the Fourteenth Amendment's creation is the critical consideration for what substantive rights are protected by the Amendment; I would take the 44-of-50 ratio today, which Justice Scalia mentioned at the McDonald oral argument but which went unmentioned in the opinion, as much more important. ${ }^{176}$ But if we are to focus on the rights prevalent when the Amendment was adopted, we should focus on the states actually adopting it.

Finally, Ryan Williams's survey of the antebellum rise of substantive due process (a term he applies to vested-rights and general-law versions of due process, not merely the sort that flowered in Munn v. Illinois and Lochner v. New York) reveals significantly stronger support for the doctrine in the South, especially in the Carolinas. ${ }^{177}$

174. Calabresi \& Agudo, supra note 172, at 51.

175. Eugene Volokh, State Constitutional Rights to Keep and Bear Arms, 11 TEX. REV. L. \& PoL. 191 (2006) (listing 12 represented Northern states with no such rights in 1867, as well as Nebraska: California (no provision, $i d$. at 194), Delaware (adopted in 1987, id. at 194), Iowa (no provision, id. at 196), Illinois (adopted in 1970, id. at 196), Maryland (no provision, id. at 197), Minnesota (no provision, id. at 198), Nebraska (adopted in 1988, id. at 199); New Hampshire (adopted in 1982, id. at 199), New Jersey (no provision, id. at 200), Nevada (adopted in 1982, id. at 199), New York (no provision, id. at 200), Wisconsin (adopted in 1998, id. at 204), and West Virginia (adopted in 1986, id. at 204). The other two states lacking state-constitutional rights to keep and bear arms in 1868, but having them today, were in the South: Louisiana (adopted in $1879, i d$. at 197) and Virginia (adopted in 1971, id. at 204)).

176. See Green, supra note 3, at 113-17.

177. Ryan Williams, The One and Only Substantive Due Process Clause, 120 YALE L.J. 408, 462-63 (2010) (noting that of the first 14 states to embrace vested-rights and law-of-generalapplicability readings of due-process or law-of-the-land provisions, 8 were among the 11 states of the Confederacy, including Tennessee); id. at 469 (counting 6 more loyal states by 1868). Williams's ratio therefore declines somewhat, from 20 out of 37 to 13 out of 26 . Williams's work shows that the vested-rights and law-of-general-applicability traditions were much shallower in the North. 


\section{CONCLUSION}

Seen as the product of a Northern author, the Fourteenth Amendment will be interpreted differently than it would if read as a North-South compromise: the concepts of due process, the privileges of citizenship, and equality were part of both Northern and Southern legal cultures, but the overlap between the two regions' versions of these ideas was not perfect. A Northern-authored Fourteenth Amendment may be in tension with the idea of the United States as a permanentlyunited nation making decisions democratically as one people. The Civil War, however, disrupted our nation's democratic unity in a way that allowed those who stayed with the Union's political apparatus to impose conditions on those who voluntary left it and later re-entered. Tacit restrictions on the scope of language are commonplace both in linguistic theory and the law of armed conflict, rendering the Republican loyal-denominator view not only intelligible but compelling. We can preserve traditional notions of uncoerced constitutional deliberation only by excluding coerced, congressionally unrepresented States from the constitutional author. This Southern forfeiture of their rights of seniority is the sort of problem that emerges elsewhere in democratic theory. The Northern power to preserve the Union by imposing conditions of loyalty more stringent than the South desired is closely akin both to the power of the current members of the Union to impose conditions on the ways in which future members may enter out of the territories, as well as to the power that a founding generation has to set rules that will inevitably affect any later generations participating in the government created by the founders. Understanding the Fourteenth Amendment's legitimacy can help us understand constitutional legitimacy more generally. 